\title{
A Framework of Major Tumor-Promoting Signal Transduction Pathways Implicated in Melanoma-Fibroblast Dialogue
}

\author{
Barbara Bellei $^{1, *}$, Emilia Migliano ${ }^{2}$ and Mauro Picardo ${ }^{1}$ \\ 1 Laboratory of Cutaneous Physiopathology and Integrated Center of Metabolomics Research, \\ San Gallicano Dermatological Institute, IRCCS, 00144 Rome, Italy; mauro.picardo@ifo.gov.it \\ 2 Department of Plastic and Regenerative Surgery, San Gallicano Dermatological Institute, IRCCS, \\ 00144 Rome, Italy; emilia.migliano@ifo.gov.it \\ * Correspondence: barbara.bellei@ifo.gov.it; Tel.: +39-0652666246
}

Received: 18 September 2020; Accepted: 13 November 2020; Published: 17 November 2020

Simple Summary: Melanoma cells reside in a complex stromal microenvironment, which is a critical component of disease onset and progression. Mesenchymal or fibroblastic cell type are the most abundant cellular element of tumor stroma. Factors secreted by melanoma cells can activate non-malignant associated fibroblasts to become melanoma associate fibroblasts (MAFs). MAFs promote tumorigenic features by remodeling the extracellular matrix, supporting tumor cells proliferation, neo-angiogenesis and drug resistance. Additionally, environmental factors may contribute to the acquisition of pro-tumorigenic phenotype of fibroblasts. Overall, in melanoma, perturbed tissue homeostasis contributes to modulation of major oncogenic intracellular signaling pathways not only in tumor cells but also in neighboring cells. Thus, targeted molecular therapies need to be considered from the reciprocal point of view of melanoma and stromal cells.

\begin{abstract}
The development of a modified stromal microenvironment in response to neoplastic onset is a common feature of many tumors including cutaneous melanoma. At all stages, melanoma cells are embedded in a complex tissue composed by extracellular matrix components and several different cell populations. Thus, melanomagenesis is not only driven by malignant melanocytes, but also by the altered communication between melanocytes and non-malignant cell populations, including fibroblasts, endothelial and immune cells. In particular, cancer-associated fibroblasts (CAFs), also referred as melanoma-associated fibroblasts (MAFs) in the case of melanoma, are the most abundant stromal cells and play a significant contextual role in melanoma initiation, progression and metastasis. As a result of dynamic intercellular molecular dialogue between tumor and the stroma, non-neoplastic cells gain specific phenotypes and functions that are pro-tumorigenic. Targeting MAFs is thus considered a promising avenue to improve melanoma therapy. Growing evidence demonstrates that aberrant regulation of oncogenic signaling is not restricted to transformed cells but also occurs in MAFs. However, in some cases, signaling pathways present opposite regulation in melanoma and surrounding area, suggesting that therapeutic strategies need to carefully consider the tumor-stroma equilibrium. In this novel review, we analyze four major signaling pathways implicated in melanomagenesis, TGF- $\beta$, MAPK, Wnt $/ \beta$-catenin and Hyppo signaling, from the complementary point of view of tumor cells and the microenvironment.
\end{abstract}

Keywords: melanoma; cancer associated fibroblast; tumor microenvironment; melanomagenesis 


\section{Introduction}

Melanoma represents approximatively $4 \%$ of skin cancer cases but is the deadliest one, corresponding to $80 \%$ of skin cancer deaths and about $1-2 \%$ of all cancer deaths [1,2]. Its incidence is rising in most countries of the western world [3]. The transformation of melanocytes into melanoma requires a burden of mutations that can be caused by both endogenous and exogenous cues [4-6]. However, genetic studies demonstrated that sporadic melanoma are associated to allele variants with high prevalence and low penetrance indicating that environmental factors play a key role in melanoma development [7-9]. Among them, the exposure to ultraviolet (UV) rays has a significant impact on skin biology and homeostasis [10]. The most deleterious effect of UV radiations is the direct damage to DNA. In addition, UVA not only contributes to the direct formation of DNA lesions but also impairs the removal of UV photoproducts from genomic DNA through oxidation and damage to DNA repair proteins [11,12]. In the epidermis, melanocytes, which are classified as intermittent mitotic cells [13] and normally divide only on demand, are more prone to accumulate damage than rapidly dividing cells such as keratinocytes. Likewise, melanocytes have a reduced repair capacity for oxidative DNA damage than skin fibroblasts [14]. Moreover, frequent excessive exposure to UV light impacts on melanocyte microenvironment within the epidermis, contributing to melanoma onset $[15,16]$. For example, alterations in the composition of basement membrane and dermal extracellular matrix might anticipate melanomagenesis, facilitating disease occurrence. In chronically sun-exposed skin, qualitative and quantitative alterations of dermal extracellular matrix proteins causing loss of tensile strength, increase fragility and impair wound healing [17]. The expression of type VII collagen that anchors fibrils at the dermal-epidermal junction by keratinocytes is decreased in UV-irradiated skin areas. UV-irradiated skin produces several enzymes such as matrix metalloproteinases (MMPs), which degrade dermal collagen fibers (especially type I collagen) and elastic fibers. This process causes an overall modification of mechanical properties of tissues that is part of the photoaging process $[18,19]$. Instead, in the contest of melanoma, MMPs altering the basement membrane and dermal ECM architecture can facilitate invasion of tumor cells. Accordingly, excessive production of MMP1, MMP2 and MMP9 has been frequently observed in melanoma patients [20-22]. Tissue surrounding benign nevi and melanomas display greater stiffness than normal skin indicating that mechanical properties of the matrix impact on melanoma initiation or progression [23]. Increasing evidence suggests that tissue rigidity or matrix stiffness controls phenotypic states and contributes to the invasive process in advanced melanoma [24]. Thus, in the skin, due to continuous extrinsic stimulation, persistent alteration in the extracellular matrix can act independently to tumor onset moving as a driver of the tumorigenic process. In addition, biological behavior of normal dermal and epidermal cells is constantly influenced by external agents. Since fibroblasts are long lived cells constantly undergoing damage accumulation, they are considered a relevant player of skin carcinogenesis. Following UV light irradiation, keratinocytes secrete melanocyte growth factor (including $\alpha$-melanocytes stimulating hormone, $\alpha$-MSH and endothelin-1, EDN1), which increase cytokine and the melanin production and transfer preventing further damage caused by UV [25-27]. In vitro, UVA and UVB activate bFGF production by both skin fibroblasts and keratinocytes [28]. Keratinocytes additionally increase the secretion of hepatocyte growth factor (HGF) and transforming growth factor- $\beta 1$ (TGF- $\beta 1$ ) inducing proliferation in melanocytes that in turn become more susceptible to transformation [29].

Transitory activation of melanocytes is part of the tanning response, the main physiological process protecting the skin from UV light. However, aberrant increased production of growth factors is considered part of the acquisition of stress-induced premature senescent phenotype and the corresponding senescence-associated secretory phenotype (SASP) as those promoted by chronic sun exposure. Correspondingly, growth factors hyperproducing senescent fibroblasts are frequently described in age spot and melasma, two pathological condition characterized by hyperpigmentation [30-33]. It is extensively documented that senescent fibroblasts accumulate in habitually sun-exposed skin and orchestrate stroma modification into a tumor-promoting one [34-37]. In line with other cancer types, the secretory profile of melanoma-associated fibroblasts largely overlaps with that of senescent 
fibroblasts [38,39]. Properly, multivariate analyses demonstrate increasing age is the strongest independent adverse prognostic factor together with Breslow thickness [40]. Tumor cells utilize fibroblast-secreted growth factors to facilitate their own survival and proliferation. The secretory profile of fibroblasts is also critical in metabolic and immune reprogramming of the tumor microenvironment with an impact on angiogenesis regulation and adaptive resistance to therapy [41-44]. Due to the intense melanoma-stoma crosstalk, fibroblasts progressively modify their biological feature, presenting a molecular signature that partially overlaps with the cancer one.

This review focuses on major intracellular signaling pathways deregulated in melanoma analyzed from the reciprocal point of view of melanoma cells and MAFs.

\section{Transformation of Normal Fibroblasts to Melanoma-Associated Fibroblasts}

Physiologically, melanocytes reside within the basal layer of the epidermis and interplay tight contacts with epidermal keratinocytes through E- and P-cadherin adhesion proteins, whereas an intense communication networks mediated by soluble factors explains the deep influence of dermal compartment in melanocyte biology [45-47]. However, during melanoma progression, there is a progressive loss of E-cadherin [48-50] and gain of N-cadherin [49,51-53], which not only frees melanoma cells from control by keratinocytes, but also provides new adhesion characteristics [54-56]. Consequently, melanoma cells acquire invasive properties, violate the basement membrane and invade the underlying dermis establishing unusual homotypic interaction between melanoma cells and heterotypic cell-cell contact with fibroblasts, endothelial and immunocompetent cells. All these elements synergistically play a specific role in disease progression. Cadherin switch as well as integrins expression profile modification also implies the activation of inappropriate survival signals $[57,58]$ and thus enhances the malignant phenotype $[51,55,59]$.

Melanoma cells actively interact with stromal cells, not only through direct cell-cell but also through cell-matrix interactions and secreted growth factors and cytokines. A complex network of soluble bioactive molecules contributes to the alteration of the host tissue and to the definition of malignant behavior of melanoma. An exclusive feature distinguishing melanoma from other tumors is the communication through melanosome, tissue-specific organelles deputies to the extracellular melanin distribution [60]. Fibroblasts around melanoma contain in their cytoplasm a significantly higher density of melanosome [61]. Melanosomes released from melanoma cells carrying pro-inflammatory molecule and several microRNA are able to transform dermal fibroblasts into pro-tumorigenic [61]. Evidence that fibroblasts begin to aggregate in the dermis at early stages of melanoma initiation, before melanoma cells invade, underlies the importance of paracrine communication between melanoma cells and surrounding. Thus, starting from early tumor stage, due to continuous paracrine stimulation by transformed cells, surrounding stromal fibroblasts are induced to initiate phenotypic, molecular and biochemical transitions and to transdifferentiate into cancer-associated fibroblasts (CAFs). Cancer-associated fibroblasts represent one of the major players in tumor-stroma network. CAFs acquire myofibroblast features and produce several growth factors that contribute to tumor cells proliferation, survival and metastasis $[42,62]$. CAFs are similar to myofibroblasts present during wound healing or the fibrotic conditions. In fact, desmoplastic wound healing-like tumor stroma is frequently referred as a consequence of mutual interaction of tumor cells and CAFs [63]. CAFs are distinguished from their normal counterparts by the expression of several markers such as alpha-smoot muscle actin $(\alpha-S M A)$, fibroblast specific protein-1 (FSP-1 also referred as S100A4), fibroblast-activating protein (FAP), platelet derived growth factor receptor-alpha/beta (PDGR $\alpha / \beta$ ), tenascin-C, collagen 11- $\alpha 1$ (COL11A1), vimentin and fibronectin. However, a univocal molecular definition of CAFs profile is yet lacking. Clinically, the presence of many myofibroblasts in the tumor microenvironment has been associated with elevated risk of invasion, metastasis and a poor prognosis [34,64]. In addition to resident fibroblasts, there are several sources of CAFs, including bone marrow mesenchymal cells and endothelial cells $[62,65]$. In the case of melanoma, due to the prevalent localization at the junction of the epidermis and the dermis, dermal fibroblasts are considered the major source of CAFs, also 
referred to as melanoma-associated fibroblasts (MAFs) [42,66-68] (Figure 1). MAFs are less frequent compared to CAFs in other solid tumors [66]. Fibroblasts are associated to melanoma cells at all stages of disease and their functional contribution to disease progression has been largely documented but now increasing data also highlight their antitumor actions [69,70]. As an extreme consequence of the intimate relationship between melanoma and fibroblast, an original study described cell fusion events capable of generating tumor-stroma cell hybrid clones [44]. It is not fully clear if the dual nature of cancer microenvironment reflects the contemporary presence of heterogenic populations or if differences reside in disease evolution. Since MAFs co-evolve with tumorigenic cells it is possible that an early anti-tumor phenotype is replaced by a pro-tumorigenic one during disease progression. In line with the idea that MAFs co-evolve with melanoma cells, several research papers demonstrated an inhibitory function of dermal fibroblasts during tumor onset. This is largely because normal dermal fibroblasts, which are mostly quiescent cells in healthy condition, function as controller of tissue homeostasis. In vitro, co-culture experiments using normal fibroblasts and cells isolated from primary melanoma evidenced repressive influence on melanoma cells [71]. Multiple factors have been implicated in the transition of normal tumor-suppressive fibroblasts into reactive and tumor-promoting CAFs [72].

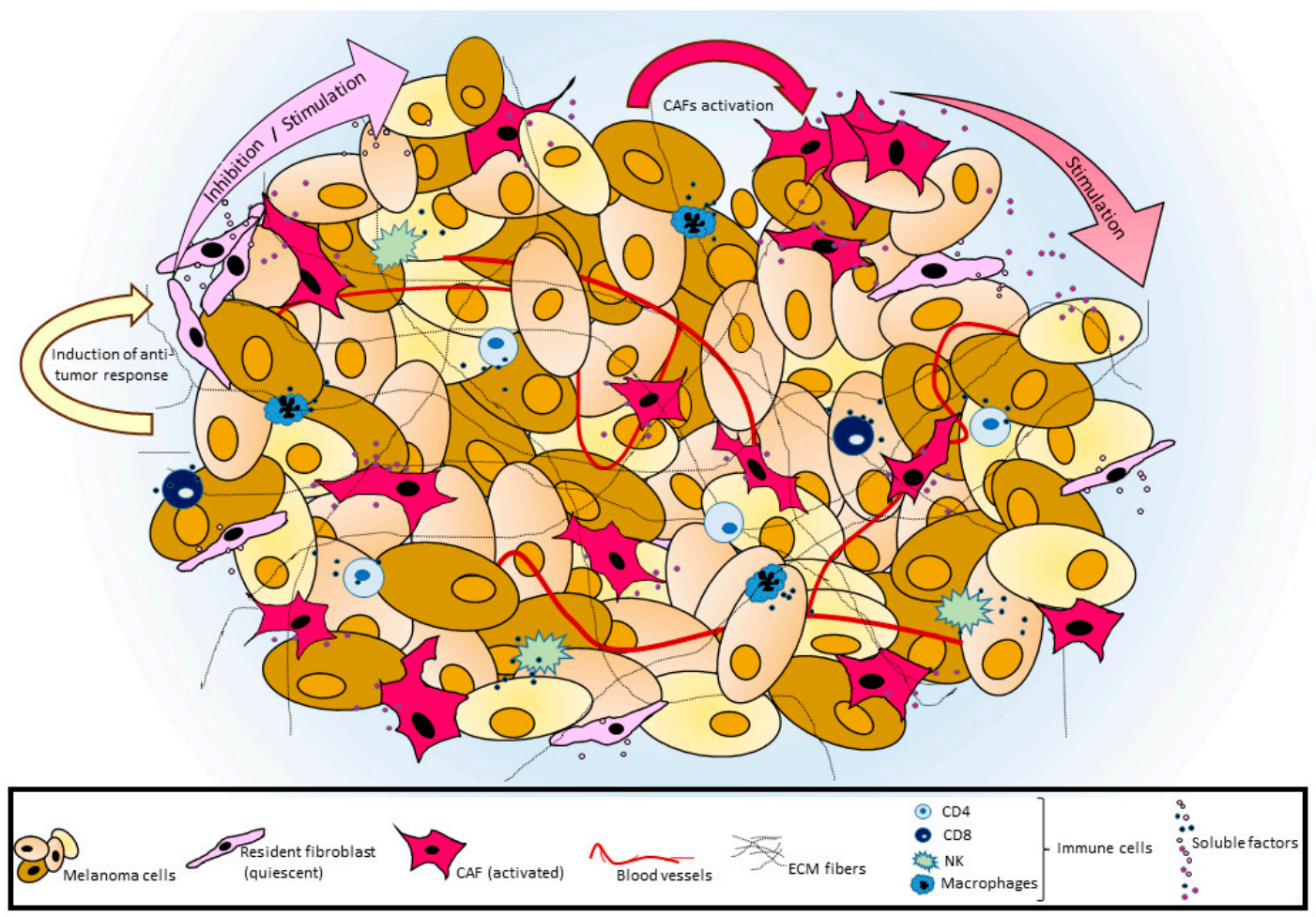

Figure 1. Schematic representation of tumor-stroma cross-talk. In melanoma, tumor cells share their microenvironment with MAFs, immune cells and blood vessels. Resident fibroblasts might oppose an early anti-tumor activity or facilitate tumor development, whereas, during disease progression, activated MAFs gradually acquire a marked pro-tumorigenic phenotype. An intense bi-directional exchange of soluble factors between melanoma and surrounding cells significantly modifies in MAFs several intracellular signaling pathways including oncogenic pathways. Extracellular matrix supports tumor architecture and influences various signal transduction pathways in both tumor and associated cells.

One of the biological behaviors of activated fibroblasts is increased proliferation rate [73]. A possible explanation of augmented proliferation of stromal cells might reside in the pro-mitogeic tumor milieu. At least during early stage of disease, the simple nearness to transformed cells could explain the involvement of non-cancerous cells that endure the extraordinary tumor secretory activity of melanoma cells. Proteomic analysis revealed that factors released in the culture medium by 
melanoma cells stimulate in dermal fibroblasts a general increase in protein synthesis. In particular, the biological process involved in fibroblast reprograming are those related to mRNA catabolic process, translation initiation, protein targeting to membrane and synthesis of metabolic-related small molecules [74,75]. Paired analysis of melanoma cells and associated MAFs revealed a trend of functionally coordinated reorganization of metabolic pathways, cytoskeleton reorganization and ECM remodeling [74]. Fibroblast reprograming is a crucial step for melanoma progression as demonstrated by the correlation between capacity of melanoma cells to alter fibroblast gene expression and the invasive potential in vitro [76]. Specifically, metastatic melanoma increases the production of cytokines and chemokines by MAFs more efficiently than nonmetastatic melanoma [76]. Among the immunomodulators involved in MAFs activation, IL1 $\beta$ seems to be a driver of melanoma invasion both in vitro and in vivo [76]. Cytokines produced by dermal fibroblasts, such as interleukin-6 and -8 (IL-6 and IL-8), interferon gamma (INF $\gamma$ ), tumor necrosis factor-alpha (TNF- $\alpha)[77,78]$ and a variety of CXCLs [37], have the capacity to mobilize immune cells. The balance between pro-inflammatory and anti-inflammatory cytokines in tumor area strongly impact on patient's prognosis. Cytokines profile supporting M1 macrophage differentiation sustain CD4+ and CD8+ T-cells infiltrating the tumor microenvironment and favorable clinical outcome, whereas alternative M2 macrophage polarization present immune-suppressive function. Since MAFs are the main producer of suppressive cytokines [46], their role in immune escape and tumor progression is relevant. MAFs suppress NK-cell activity and CD8+ cytotoxic activity [66,79]. Release of IL-8, CCL2/MCP1 (monocyte chemoattractant protein-1) and tissue inhibitor of metalloproteinase 2 (TIMP-2) by fibroblasts when co-cultured with melanoma cells has also been implicated in the angiogenic process indicating that recruitment of microvascular endothelial cells depends on the synergic melanoma-fibroblast network [80].

Considering all these pleiotropic roles, MAFs are considered a promising target for melanoma therapy. Essentially, targeting CAFs has been investigated by using agents aiming to eliminate or reprogram CAFs. However, in mouse model, reduced stromal content accelerates tumor growth and angiogenesis and full depletion of CAFs induces immunosuppression [81,82]. Thus, based on fibroblasts exceptional phenotypic plasticity, therapeutic re-orientation of CAFs to an anti-tumor phenotype seems to be more promising. Therefore, to efficiently reprogram CAFs' activity against tumor, we need to exactly know the contribution of stromal fibroblasts in a specific tumor type and to promote exclusively anti-neoplastic properties.

\section{Significance of Altered Intracellular Signal Transduction Pathways in Melanoma and Associated Fibroblasts}

\subsection{Wnt Signaling}

Signal activation due to the Wnt family of secreted glycoproteins is involved in embryogenic development, cell polarity, tissue homeostasis and cell proliferation in adult stage $[83,84]$. $\beta$-catenin is the key protein regulating Wnt signaling-mediated gene expression [85]. Moreover, $\beta$-catenin is deeply implicated in cadherin-based cell adhesion [86,87]. In the absence of Wnt ligands, $\beta$-catenin is recruited into a destruction complex that contains adenomatous polyposis coli (APC) and AXIN, which facilitates the phosphorylation of $\beta$-catenin by casein kinase 1 (CK1) and then glycogen synthase kinase-3 beta (GSK3 $\beta$ ) leading to its ubiquitylation and proteasomal degradation. Following the binding of Wnt factors to their receptors (frizzled, FZD and low-density lipoprotein receptor protein 5/6 (LPR5/6)), cytosolic GSK-3 $\beta$ is sequestered, and the phosphorylation of $\beta$-catenin is prevented. The blocking of $\beta$-catenin degradation leads to its stabilization in the cytosol and consequent translocation into the nucleus, where it binds to members of lymphoid enhancer-binding factor (LEF)/T-cell specific factor (TCF) family and some other co-regulators to promote the transcription of ubiquitous genes such as Jun, $c-M y c$ and CyclinD-1, most of which encode oncoproteins $[88,89]$. In addition, $\beta$-catenin is a co-activator for the expression of melanocyte-lineage restricted genes including Microphthalmia-associated Transcription Factor-M (MITF-M) [90-92], Dopachrome Tautomerase (DCT) [91,93-95] and Brn-2 [96]. The ability of $\mathrm{Wnt} / \beta$-catenin signaling to drive the expression of differentiation-related genes reflects its critical role in 
melanocyte development $[91,97,98]$ and adult melanocyte stem cells mobilization $[99,100]$. Given peculiar involvement of $\beta$-catenin in both proliferation and differentiation of melanocytes, it is not surprising that in this type of cells its expression level is subjected to tight regulation. For example, in normal melanocytes in vitro, reduced $\beta$-catenin gene transcript by RNA interfering leads to a rapid stabilization of the corresponding protein capable of restoring the physiological level of expression [101].

As demonstrated in numerous studies, the aberrant activation of Wnt signaling contributes to malignant cell transformation and neoplastic proliferation with further metastatic dissemination and resistance to treatment [102-105]. Deregulations in the canonical Wnt signaling in cancer may result from gain-of-function gene alterations and epigenetic mechanisms. Nonetheless, $\beta$-catenin, APC and AXIN2 mutations are rare in primary melanoma specimens [101,106-111], in comparison to well-characterized melanoma cell lines cultured in vitro for a long period [112]. This suggests that elevated $\beta$-catenin protein level confers proliferative advantage under a selective pressure such as in vitro cell growth. In melanoma, epigenetic regulation of Wnt antagonists such as Dickkopf proteins (DKKs), Wnt inhibitor factor-1 (WIF1) and soluble frizzled-related protein-2 sFRP2 contributes substantially to cell-autonomous activation of Wnt/ $\beta$-catenin signaling $[113,114]$. DKK2 and DKK3 have been found upregulated in the good-prognosis melanoma patients presenting basal high immune signature [115]. Unlike most cancers, where Wnt signaling is considered a driver of both tumor formation and progression, in human melanoma, there are contradictory results [116-118]. The major discrepancies emerged from the comparison between studies performed with melanoma cell culture model and investigations based on immunohistochemical analyses in skin biopsy and clinical outcome. In vitro studies proposed that an increased nuclear translocation and activity of $\beta$-catenin promote melanoma proliferation [119] and invasion [105]. By contrast, diverse studies linked the activation of $\mathrm{Wnt} / \beta$-catenin signaling to decreased proliferation [120] and repressed invasion [121] and migration [122]. In vivo observations from melanoma patients indicated that nuclear $\beta$-catenin correlates with improved survival [120-123]. Furthermore, almost all benign nevi are positive for nuclear $\beta$-catenin $[124,125]$. Adding complexity to this scenario, changes in Wnt signaling pathway have been linked to phenotype switching of melanoma cells between a highly proliferative/non-invasive (high $\beta$-catenin expressing cells) and a slow proliferative/metastatic (low $\beta$-catenin expressing cells) condition [126-129]. These data collectively suggest that the ambiguous role of Wnt pathway activation in melanoma strongly depends on the combination of both intracellular and microenvironmental contexts. The expression and transcriptional activity of $\beta$-catenin inversely correlate to immune activation and it has been proposed as a predictive marker of immunotherapy response $[115,116,130-134]$. The mechanism by which $\beta$-catenin promotes resistance to immunotherapy involves the reduced secretion of attractant chemokines that allows impaired infiltration and activation of dendritic and T cells [130]. Conversely, MAPK inhibitors demonstrated an enhanced efficacy in cultured melanoma cell lines with activated Wnt/ $\beta$-catenin signaling $[135,136]$. However, in line with the idea that patient's immune activity contributes to MAPK inhibitors outcome, in vivo studies did not confirmed improvements in patient's survival presenting intrinsic $\beta$-catenin activation [137].

In the tumor background, in addition to genetic and epigenetic mechanisms, increased paracrine factors from the surrounding tissue might contribute for the activation of Wnt signaling in tumor cells [138]. Among these, Wnt ligands and several growth factors are frequently hyperproduced by CAFs $[139,140]$ such as hepatocyte growth factor (HGF) [141] and platelet-derived growth factor (PDGF) [142]. It has been proposed that elevated level of sFRP2, a Wnt antagonist, secreted by aged fibroblasts could facilitate the acquisition of a metastatic, therapy-resistant state of melanoma [143]. Modification of Wnt pathway modulators in melanoma cells, including Wnt5a [128,144,145], Wnt7b, Wnt10b [146], Frizzled-3 (FZD3) [130] and DKKs [113] has been largely investigated as a cell autonomous mechanism responsible of signaling activation in tumor cells. However, this intense secretory activity might also deeply influence neighboring cell populations. Interestingly, Wnt ligands secreted by tumor cells could stimulate the polarization of tumor-associated macrophages (TAMs) to M2 tumor promoting subtype via Wnt signaling [147]. Thus, tumor paracrine activity might also play a relevant role in Wnt signaling regulation 
of other skin cell types, including mesenchymal cells. In dermal fibroblasts, transient stimulation of $\mathrm{Wnt} / \beta$-catenin signaling is associated to an activated state of this type of cells during tissue repair [148-151]. Sustained Wnt/ $\beta$-catenin activation in dermal fibroblasts is involved in pathogenesis of fibrotic diseases including hyperplastic wounds [152] and keloids [153-155]. Stroma recruited by melanoma resembles fibrotic microenvironment of persistent wound healing, since the entire tissue experiences a chronic injury due to the damage caused by tumor growth. As with other cancers, nuclear and cytoplasmic $\beta$-catenin has been demonstrated highly expressed in MAFs located around and in the melanoma tissue [72]. In 3D multicellular tumor spheroid model and in in vivo mouse melanoma model, skin fibroblasts ablated for $\beta$-cateningene demonstrated reduced ability to support the growth of B16F10 melanoma cells [70,72]. In this case, the observed reduced number of stromal fibroblasts partially explain the diminished inhibitory effect of dermal fibroblast on melanoma formation. However, deactivation of $\beta$-catenin also weakens the expression of HGF and ECM proteins in residual fibroblasts [72,156]. Interestingly, $\beta$-catenin loss in fibroblast affects the RAF-MEK-ERK signaling cascade suppressing melanoma cell proliferation and cells death at the same time [72,157]. Shao and co-workers reported that the expression of Wnt-induced secreted protein-1 (WISP-1), a $\beta$-catenin target gene, is almost undetectable in areas with melanoma and in the surrounding tissue, whereas strong expression has been observed in non-activated fibroblasts of uninvolved skin [158] indicating a negative correlation between WISP-1 expression and a permissive tumor microenvironment. However, in this case, deregulated WISP-1 expression has been linked to the suppression of Notch signaling in MAFs rather than to the activity of Wnt pathway. As observed for other mesenchymal cells, independently of the presence of Wnts ligand at the extracellular level, Wnt signaling could be coordinately modulated in melanoma and stromal cells also by tissue stiffness [159]. Activation $\mathrm{Wnt} / \beta$-catenin signaling in response to change in substrate stiffness might be stabilized or reinforced by a positive feedback loop based on the transcription of the $\beta$-catenin target gene wnt-1 [159].

\subsection{Hippo Signaling}

Hippo signaling is an important regulator of cell proliferation and survival in animals playing a critical role in organ size control, stem cells homeostasis, cell polarity and shape [160,161]. The Hippo pathway is regulated upstream by extracellular mechanosensory signals arising from perturbation of actin cytoskeleton and adhesion change, as well as by a variety of extracellular signaling molecules. Hippo activity is deregulated in many cancers, despite mutations of pathway components are uncommon especially in melanoma [162,163]. Alteration of gene copy number among Hippo pathway elements have been frequently observed [164]. The Hippo signaling pathway includes a kinase cascade that modulates different proteins in order to phosphorylate and inactivate its main downstream cytosolic effectors, yes-associated protein (YAP) and tafazzin (TAZ), which direct gene expression via control of the Transcriptional enhancer factor (TEAD) family of transcription factors $[165,166]$. Nuclear YAP/TAZ interact with several important transcription factor including TCF/LEF, small mother against decapentaplegic factors (SMADs), cAMP response element-binding protein (CREB), myoblast determination protein $1(\mathrm{MyoD})$ and tumor protein p73 (TP73) controlling cell proliferation and apoptosis [167-169]. This pathway is thought to be central to uveal melanomagenesis as YAP is hyperactive in uveal melanoma cells and mediates the oncogenic effect of guanine nucleotide binding protein (G protein) q polypeptide (GNAQ), or G protein $\alpha 11$ (GNA11) mutations, which occur in approximately $80 \%$ of these type of melanoma $[170,171]$. YAP protein expression is elevated in most benign nevi and primary cutaneous melanomas but present at only very low levels in normal melanocytes [163]. Furthermore, since Hippo pathway is modulated by adhesion change and mechanical signaling, there is a strong possibility that extracellular stimuli from the melanoma microenvironment such as ECM modification might therefore impact on its activation. In melanoma patients, increased collagen and fibronectin abundance correlates with YAP nuclear localization [24]. Further analysis of the same patient cohort evidenced that melanoma cells positive for YAP nuclear staining present elevated MITF expression and a proliferation/differentiation signature. Proliferation and differentiation are not mutually exclusive events in the melanocyte lineage and are both promoted by MITF. By contrast, low level of MITF 
are associated to a dedifferentiated/invasive phenotype [126,172]. Several other studies indicated that hyperactive YAP is sufficient to drive cells switch from proliferative to invasive phenotype $[173,174]$. In murine xenograft model silencing the expression of YAP and TAZ results in reduced proliferation of human melanoma cell lines and decreases lung metastasis [133]. The E-cadherin/catenin complex functions as an upstream regulator of the Hippo signaling combining loss of E-cadherin at the cell surface with $\beta$-catenin and YAP nuclear accumulation [175]. Added evidence demonstrated cross-regulation between $W n t / \beta$-catenin and Hippo signaling: TAZ is targeted for degradation by the $\beta$-catenin destruction complex [176,177]. On the other hand, YAP and TAZ can retain $\beta$-catenin in cytoplasm limiting Wnt $/ \beta$-catenin signaling [178]. Thus, YAP and TAZ can be viewed as integral components of the Wnt $/ \beta$-catenin signaling pathway in addition to their role in Hippo signaling $[178,179]$. Interestingly, TGF- $\beta$ produced by stromal fibroblasts might exert a fine regulation of YAP transcriptional activity promoting YAP/SMAD interaction instead of YAP/PAX3 transcription complex redirecting cells to a less differentiated more aggressive state similar to melanocyte stem cells [24].

In cutaneous melanoma, evidence from cell lines supports not only a role of YAP/TAZ in cell invasion but also in resistance to target therapy and immunotherapy $[171,180,181]$. YAP promotes PD-1 expression driving immune evasion in BRAF inhibitors-resistant melanoma $[181,182]$. However, opposite to tumor cells, activation of YAP and TAZ in CAF exerts a tumor-suppressive function. In fact, deletion of $Y A P$ and $T A Z$ in these peritumoral cells accelerated primary liver tumor growth. Experimental hyperactivation of YAP in peritumoral hepatocytes triggered regression of melanoma-derived liver metastasis. Since tumor cell survival depend on the relative activity of YAP and TAZ tumor and surrounding tissue, it has been hypothesized that the major function of YAP/TAZ in tumor cells is to elevate their competitive fitness and to "protect" them from the tumor-suppressive action of the surrounding parenchyma [182]. According to the concept of cell competition, an interesting point resides in the concept that it is the relative level and not the absolute level of a molecular pathway (not only Hippo pathway) that determines which cells (peritumoral or tumoral) lose competition. On the other hand, acquired mutations render cancer cells more competitive than non-neoplastic cells compromising tumor elimination [183].

\subsection{TGF- $\beta$ Signaling}

The transforming growth factors (TGF)- $\beta$ family of growth factors are secreted multifunctional cytokines that signals via plasma membrane TGF- $\beta$ type I and type II receptors and intercellular small mother against decapentaplegic (SMADs) transcriptional effectors [184]. TGF- $\beta$ controls tissue remodeling during embryonic development, angiogenesis, tissue repair and several cellular functions, such as cell growth, adhesion, recognition, cell fate determination and apoptosis $[185,186]$. In the skin, TGF- $\beta$ is important for the wound healing process, especially in burn wounds [187]. TGF- $\beta$ has a dual action in cancer as a tumor suppressor and a tumor promoter. As a tumor suppressor, it inhibits tumorigenesis by inducing growth arrest and apoptosis. As a tumor promoter, it induces tumor cell migration and stimulates epithelial to mesenchymal transition, a process during which cancer cells lose epithelial features and activate genes that increases cell motility and dissemination $[35,36,188]$.

Alterations of TGF- $\beta$ signaling, including loss-of-function mutations in genes encoding TGF- $\beta$ receptors or SMAD proteins, confer escape from the antiproliferative activity of TGF- $\beta$ [189]. Melanoma produces increasing amounts of TGF- $\beta$ with disease progression [190,191], providing an optimal microenvironment for undisturbed tumor growth. Contrary to other tumor types, no genetic alteration of TGF- $\beta$ signaling molecules has been identified in melanoma [192]. Among different forms, TGF- $\beta 1$ is secreted by normal melanocytes and melanomas at various stages, while TGF- $\beta 2$ and TGF- $\beta 3$ levels rise early in melanoma and increase with tumor progression [193]. In addition, a correlation between TGF- $\beta 2$ expression and tumor thickness has been reported [194]. Although melanoma cells efficiently respond to TGF- $\beta$ at the receptor level, in contrast to normal melanocytes, melanoma cells display various degree of desensitization to the growth inhibitory activity of TGF- $\beta$. Resistance to the growth inhibitory activity of TGF- $\beta$ has been explained by the frequent aberrant activation of MAPK pathway 
in melanoma that is capable to reprogram intracellular TGF- $\beta$ cascade [192]. Similar to wound-healing process, tumor-derived TGF- $\beta$ is likely to recruit other stromal cells. It is well demonstrated that transforming growth factor- $\beta$ produced by tumor cells may promote tumor growth and advancement by modifying the microenvironment [56]. Forced overexpression of TGF- $\beta 1$ by melanoma cells activates stromal fibroblasts, leading to augmented collagen, fibronectin, tenascin and $\alpha 2$ integrin expression. In experimental mouse model, tumors generated by subcutaneous co-injection of fibroblasts with melanoma cells demonstrated that TGF- $\beta$-overexpressing melanoma cells exhibit fewer necrotic and apoptotic cells and form more lung metastases than control melanoma cells [22]. Thus, activation of stromal fibroblasts by tumor-derived TGF- $\beta$ provides an optimal microenvironment for tumor progression and metastasis [56,64]. Autocrine loop based on TGF- $\beta$ and stromal derived factor 1 (SDF-1) is necessary for the consolidation of activated CAF phenotype $[43,195]$. Mechanical stress is the second major factor for myofibroblasts activation [64,196]. Initial small changes in tissue stiffness occur during the inflammatory response in tumor development and seem to be induced by increased collagen production and crosslinking $[197,198]$. Secondarily, stiff ECM promotes myofibroblast phenotypic conversion improving the efficiency of latent TGF $\beta 1$ activation [64]. Metastatic and primary melanoma cell lines overexpress collagen VI and in vivo the level of this type of collagen positively correlates to advanced stages $[197,199]$. Hyperactive TGF- $\beta$ signaling associated to loss of caveolin-1 promotes tumorigenesis by shifting fibroblasts toward catabolic metabolism, a mechanism that generates energy-rich metabolites [43,200]. Another member of the TGF superfamily, Nodal, an embryonic morphogen not expressed in healthy adult tissues, has been demonstrated highly present in MAFs in vivo and in vitro [201,202]. Fibroblasts activated by Nodal, promote melanoma proliferation in vitro and in xenograft tumor models. A recent study demonstrated that the extremely high level of TGF- $\beta 1$ produced by melanoma cells and detected in patients' sera is also capable to activate fibroblasts of distant uninvolved skin [203]. This is of particular interest since recruitment of MAFs also supports the generation of metastatic niche necessary for invasion of distant organs [204]. Based on this observation, it is possible to extend, at least in advanced disease stage, the concept of melanoma microenvironment on the entire body.

\subsection{MAPK Signaling}

The mitogen-activated protein kinase (MAPK) pathway activation is a critical player in the biology of different types of cancer and is the most frequent pathway aberrantly activated in melanoma [205]. Up to $70 \%$ of melanomas exhibit activating mutations within the kinases BRAF gene [206-209] and approximately $15 \%$ of melanomas within $N R A S$ gene [210,211], resulting in constitutive and sustained activation of downstream targets, RAS-MEK-ERK1/2 axis, in addition to unresponsive negative feedback mechanisms [212]. In BRAF and NRAS mutated cells, MAPK cascade is turned on without the need of ECM signaling or growth factors thereby allowing to proliferation, survival and cell transformation [213]. However, by itself oncogenic BRAF is not sufficient for melanoma and must cooperate with other processes to induce the fully cancerous state. In fact, $B R A F$ is mutated in up to $80 \%$ of the benign nevi [214]. Indeed, nevi remain growth-arrested for decades and rarely progress into melanomas $[215,216]$ presumably because aberrant BRAF signaling induces a robust senescence response mediated by upregulation of the cell cycle inhibitor p16 [217-219]. Escape from BRAF-induced senescence requires cooperation with other oncogenic process including additional DNA damage, epigenetic mechanisms, loss of PTEN, activation of PI3K/AKT and mTOR signaling, as well as metabolic reprogramming. In addition, microenvironmental mediators might directly and indirectly influence MAPK pathway activity in melanocyte lineage. Nevus melanocytes secrete several molecules belonging the SASP [220], a powerful autocrine/paracrine mechanism for the maintenance of the senescent state. Although BRAF mutation and activation of the MAPK pathway is important in nevogenesis, MAPK pathway activation do not appear to persist at high levels in nevi after growth arrest [214-221]. However, due to the potent re-activation of MAPK pathway in melanoma [222] selective BRAF inhibitors are used in the treatment of patients with BRAF-mutant 
advanced melanoma $[223,224]$. Unfortunately, patients frequently develop mutation-independent resistance to this therapy. Acquired resistance is mostly driven by the secretory activity of TAMs and MAFs [225-227].

Although TGF- $\beta$ released locally from BRAF-inhibitor treated melanoma cells appeared to constitute an important mechanism of fibroblast activation, there is also evidence that the introduction of mutant BRAF into melanoma cells increases their secretion of interleukin (IL)- $1 \alpha$ that causes tumor-associated fibroblasts to induce immune suppression [228]. In fibroblasts, the expression of mitogen-activated protein kinase kinase 1 (MAPKK1) is strongly induced by melanoma cells secretome [75]. Several studies underlined the key role of fibroblast-derived cytokines in MAPK inhibitor tolerance [225-229]. This effect is mostly due to the non-negligible direct effect of this class of compound on BRAF wild type surrounding non-melanoma cells. BRAF inhibition might lead to a paradoxical activation of MAPK in fibroblasts increasing the production of survival factor as neuregulin (NRG) and HGF [229]. Further, as an indirect effect, MAPKi-treated melanoma cells stimulate macrophages to produce IL-1 $\beta$ that in turn lead to the conversion of fibroblast into a melanoma-protective phenotype [225]. In a very interesting study, Hirata and collaborators demonstrated that BRAF inhibitors promote the formation of dense collagen fibrils and an overall increased matrix deposition by MAFs that render BRAF-mutant melanoma cells insensitive to treatment. Remodeled ECM leads to adhesion-dependent (integrin and focal adhesion-dependent) signaling to ERK that negates the effect of BRAF inhibition in the melanoma cells. Histological examination of melanoma sample from vemurafenib-resistant patients confirmed increased fibroblastic stroma and stiffer matrix once resistance to BRAF inhibitors had developed [230].

\section{Conclusions}

A huge number of studies documented that the imbalance of cellular homeostasis during melanomagenesis combines oncogenic transformation of melanocytes within altered tumor stroma. Thus, from the therapeutic point of view, tumor and stroma might be considered a unique functional unit. In melanoma, most of the targetable signal transduction pathways are correspondingly altered in MAFs, suggesting that target therapies presumably deeply impact on microenvironment biological behavior. Contextual modulation of oncogenic signal cascades in MAFs might arise from extrinsic stimuli (e.g., preexisting chronic tissue damage), melanoma-induced activation and stimulation by therapeutic pressure. On the other hand, in line with symmetric bi-directional cancer-fibroblast crosstalk, the competition imposed by antitumor function of tumor microenvironment might elicit activation of intracellular signaling in tumor cells exacerbating neoplastic phenotype. ECM remodeling seems to play a central role in melanoma biology since the activation of important signal transduction pathways involved in melanomagenesis are extremely sensible to mechanotransduction. This point of view implies a shift of the therapeutic approach from the neoplastic cell-centric to a stroma-centric consideration (Figure 2). Full characterization of CAFs might be considered part of the customization of healthcare. As discussed in this review, molecules already used in clinical practice, such as MAPKi, or which are in the preclinical study phase should be reevaluated considering the intercellular molecular dialogue of neoplastic and non-neoplastic cells. In our opinion, the development of strategies able to simultaneously target melanoma cells and MAFs represents an extraordinary opportunity in the current setting of precision cancer medicine. 


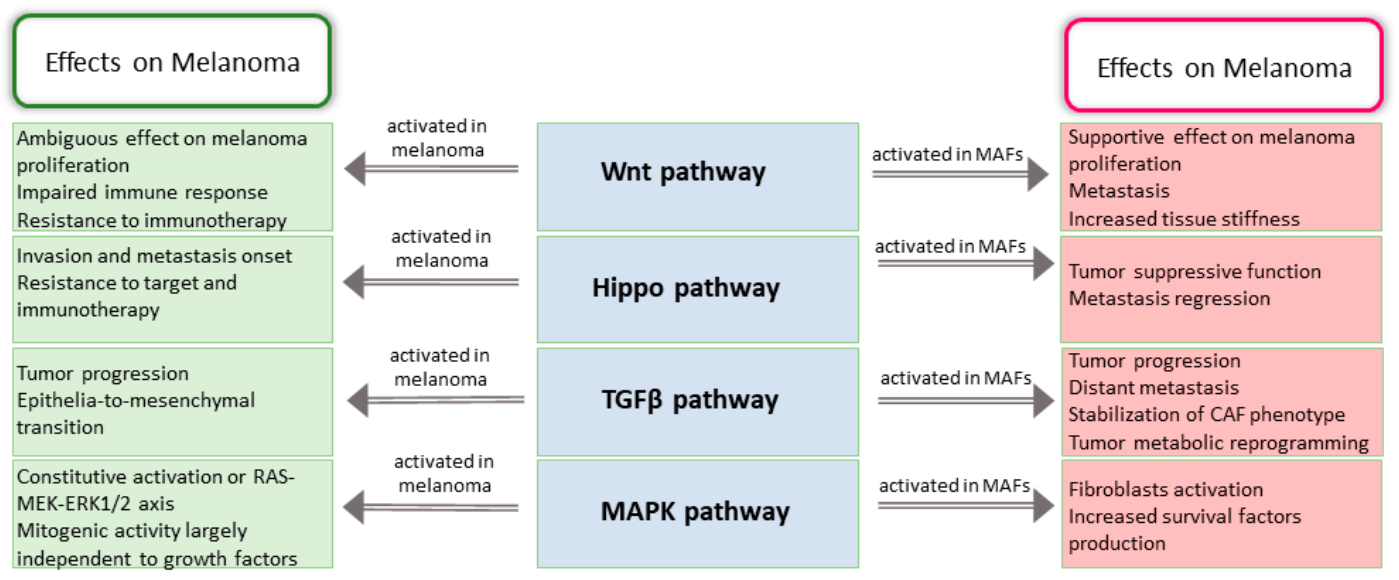

Figure 2. Tumor promoting function of oncogenic pathways deregulated in CAFs. Scheme recapitulates data presented concerning Wnt, Hippo, TGF $\beta$ and MAPK pathways deregulation in MAFs and melanoma cells. Mostly, activation of these pathways in MAFs exerts a pro-tumorigenic effect with the exception of Hippo signaling that trigger a competition between tumor and stroma characterized by a tumor-suppressive function.

Author Contributions: B.B. planned the review and prepared the manuscript. E.M. contributed to analyzing clinical data. M.P. coordinated all the activities. All authors have read and agreed to the published version of the manuscript.

Funding: This research received no external funding.

Conflicts of Interest: The authors declare that they have no known competing financial interests or personal relationships that could have appeared to influence the work reported in this paper.

\section{References}

1. Miller, A.J.; Mihm, M.C., Jr. Melanoma. N. Engl. J. Med. 2006, 355, 51-65. [CrossRef]

2. Houghton, A.N.; Polsky, D. Focus on Melanoma. Cancer Cell. 2002, 2, 275-278. [CrossRef]

3. Arnold, M.; Holterhues, C.; Hollestein, L.M.; Coebergh, J.W.; Nijsten, T.; Pukkala, E.; Holleczek, B.; Tryggvadóttir, L.; Comber, H.; Bento, M.J.; et al. Trends in incidence and predictions of cutaneous melanoma across Europe up to 2015. J. Eur. Acad. Dermatol. Venereol. 2014, 28, 1170-1178. [CrossRef] [PubMed]

4. Sun, X.; Zhang, N.; Yin, C.; Zhu, B.; Li, X. Ultraviolet radiation and melanomagenesis: From mechanism to immunotherapy. Front. Oncol. 2020, 10, 951. [CrossRef] [PubMed]

5. Palmieri, G.; Colombino, M.; Casula, M.; Manca, A.; Mandalà, M.; Cossu, A. Italian Melanoma Intergroup (IMI). Molecular pathways in melanomagenesis: What we learned from next-generation sequencing approaches. Curr. Oncol. Rep. 2018, 20, 86. [CrossRef] [PubMed]

6. Shain, A.H.; Bastian, B.C. From melanocytes to melanomas. Nat. Rev. Cancer 2016, 16, 345-358. [CrossRef] [PubMed]

7. Eggermont, A.M.; Spatz, A.; Robert, C. Cutaneous melanoma. Lancet 2014, 383, 816-827. [CrossRef]

8. Hawryluk, E.B.; Tsao, H. Melanoma: Clinical features and genomic insights. Cold Spring Harb Perspect. Med. 2014, 4, a015388. [CrossRef] [PubMed]

9. Landi, M.T.; Kanetsky, P.A.; Tsang, S.; Gold, B.; Munroe, D.; Rebbeck, T.; Swoyer, J.; Ter-Minassian, M.; Hedayati, M.; Grossman, L.; et al. MC1R, ASIP, and DNA repair in sporadic and familial melanoma in a mediterranean population. J. Natl. Cancer Inst. 2005, 97, 998-1007. [CrossRef]

10. Sample, A.; He, Y.Y. Mechanisms and prevention of UV-induced melanoma. Photodermatol. Photoimmunol. Photomed. 2018, 34, 13-24. [CrossRef]

11. Schulman, J.M.; Fisher, D.E. Indoor ultraviolet tanning and skin cancer: Health risks and opportunities. Curr. Opin. Oncol. 2009, 21, 144-149. [CrossRef] [PubMed]

12. Sarkar, S.; Gaddameedhi, S. Solar ultraviolet-induced DNA damage response: Melanocytes story in transformation to environmental melanomagenesis. Environ. Mol. Mutagen. 2020, 61, 736-751. [CrossRef] [PubMed] 
13. Cichorek, M.; Wachulska, M.; Stasiewicz, A.; Tymińska, A. Skin melanocytes: Biology and development. Postepy Dermatol. Alergol. 2013, 30, 30-41. [CrossRef] [PubMed]

14. Wang, H.T.; Choi, B.; Tang, M.S. Melanocytes are deficient in repair of oxidative DNA damage and UV-induced photoproducts. Proc. Natl. Acad. Sci. USA 2010, 107, 12180-12185. [CrossRef]

15. Khan, A.Q.; Travers, J.B.; Kemp, M.G. Roles of UVA radiation and DNA damage responses in melanoma pathogenesis. Env. Mol. Mutagen. 2018, 59, 438-460. [CrossRef]

16. Mo, X.; Preston, S.; Zaidi, M.R. Macroenvironment-gene-microenvironment interactions in ultraviolet radiation-induced melanomagenesis. Adv. Cancer Res. 2019, 144, 1-54.

17. Zhang, S.; Duan, E. Fighting against skin aging: The way from bench to bedside. Cell Transplant. 2018, 27, 729-738. [CrossRef]

18. Naylor, E.C.; Watson, R.E.; Sherratt, M.J. Molecular aspects of skin ageing. Maturitas 2011, 69, $249-256$. [CrossRef]

19. Yaar, M.; Gilchrest, B.A. Photoageing: Mechanism, prevention and therapy. Br. J. Dermatol. 2007, 157, 874-887. [CrossRef]

20. Chen, Y.; Chen, Y.; Huang, L.; Yu, J. Evaluation of heparanase and matrix metalloproteinase-9 in patients with cutaneous malignant melanoma. J. Dermatol. 2012, 39, 339-343. [CrossRef]

21. Rotte, A.; Martinka, M.; Li, G. MMP2 expression is a prognostic marker for primary melanoma patients. Cell Oncol. (Dordr.) 2012, 35, 207-216. [CrossRef]

22. Berking, C.; Takemoto, R.; Schaider, H.; Showe, L.; Satyamoorthy, K.; Robbins, P.; Herlyn, M. Transforming growth factor-beta1 increases survival of human melanoma through stroma remodeling. Cancer Res. 2001, $61,8306-8316$.

23. Kirkpatrick, S.J.; Wang, R.K.; Duncan, D.D.; Kulesz-Martin, M.; Lee, K. Imaging the mechanical stiffness of skin lesions by in vivo acousto-optical elastography. Opt. Express 2006, 14, 9770-9779. [CrossRef]

24. Miskolczi, Z.; Smith, M.P.; Rowling, E.J.; Ferguson, J.; Barriuso, J.; Wellbrock, C. Collagen abundance controls melanoma phenotypes through lineage-specific microenvironment sensing. Oncogene 2018, 37, 3166-3182. [CrossRef]

25. Natarajan, V.T.; Ganju, P.; Ramkumar, A.; Grover, R.; Gokhale, R.S. Multifaceted pathways protect human skin from UV radiation. Nat. Chem. Biol. 2014, 10, 542-551. [CrossRef]

26. Wang, J.X.; Fukunaga-Kalabis, M.; Herlyn, M. Crosstalk in skin: Melanocytes, keratinocytes, stem cells, and melanoma. J. Cell. Commun. Signal. 2016, 10, 191-196. [CrossRef]

27. Maresca, V.; Flori, E.; Bellei, B.; Aspite, N.; Kovacs, D.; Picardo, M. MC1R stimulation by alpha-MSH induces catalase and promotes its Re-distribution to the cell periphery and dendrites. Pigment Cell. Melanoma Res. 2010, 23, 263-275. [CrossRef]

28. Brenner, M.; Degitz, K.; Besch, R.; Berking, C. Differential expression of melanoma-associated growth factors in keratinocytes and fibroblasts by ultraviolet A and ultraviolet B radiation. Br. J. Dermatol. 2005, 153, 733-739. [CrossRef]

29. Berking, C.; Takemoto, R.; Satyamoorthy, K.; Elenitsas, R.; Herlyn, M. Basic fibroblast growth factor and ultraviolet B transform melanocytes in human skin. Am. J. Pathol. 2001, 158, 943-953. [CrossRef]

30. Kovacs, D.; Cardinali, G.; Aspite, N.; Cota, C.; Luzi, F.; Bellei, B.; Briganti, S.; Amantea, A.; Torrisi, M.R.; Picardo, M. Role of fibroblast-derived growth factors in regulating hyperpigmentation of solar lentigo. Br. J. Dermatol. 2010, 163, 1020-1027. [CrossRef]

31. Lin, C.B.; Hu, Y.; Rossetti, D.; Chen, N.; David, C.; Slominski, A.; Seiberg, M. Immuno-histochemical evaluation of solar lentigines: The association of KGF/KGFR and other factors with lesion development. J. Dermatol. Sci. 2010, 59, 91-97. [CrossRef]

32. Passeron, T.; Picardo, M. Melasma, a photoaging disorder. Pigment Cell. Melanoma Res. 2018, 31, 461-465. [CrossRef]

33. Imokawa, G. Autocrine and paracrine regulation of melanocytes in human skin and in pigmentary disorders. Pigment Cell Res. 2004, 17, 96-110. [CrossRef]

34. Mellone, M.; Hanley, C.J.; Thirdborough, S.; Mellows, T.; Garcia, E.; Woo, J.; Tod, J.; Frampton, S.; Jenei, V.; Moutasim, K.A.; et al. Induction of fibroblast senescence generates a non-fibrogenic myofibroblast phenotype that differentially impacts on cancer prognosis. Aging (Albany N. Y.) 2016, 9, 114-132. [CrossRef]

35. Ahmadi, A.; Najafi, M.; Farhood, B.; Mortezaee, K. Transforming growth factor- $\beta$ signaling: Tumorigenesis and targeting for cancer therapy. J. Cell. Physiol. 2019, 234, 12173-12187. [CrossRef] 
36. Miyazono, K.; Katsuno, Y.; Koinuma, D.; Ehata, S.; Morikawa, M. Intracellular and extracellular TGF- $\beta$ signaling in cancer: Some recent topics. Front. Med. 2018, 12, 387-411. [CrossRef]

37. Alspach, E.; Fu, Y.; Stewart, S.A. Senescence and the pro-tumorigenic stroma. Crit. Rev. Oncog. 2013, 18, 549-558. [CrossRef]

38. Kim, E.; Rebecca, V.; Fedorenko, I.V.; Messina, J.L.; Mathew, R.; Maria-Engler, S.S.; Basanta, D.; Smalley, K.S.; Anderson, A.R. Senescent fibroblasts in melanoma initiation and progression: An integrated theoretical, experimental, and clinical approach. Cancer Res. 2013, 73, 6874-6885. [CrossRef]

39. Moinfar, F.; Beham, A.; Friedrich, G.; Deutsch, A.; Hrzenjak, A.; Luschin, G.; Tavassoli, F.A. Macro-environment of breast carcinoma: Frequent genetic alterations in the normal appearing skins of patients with breast cancer. Mod. Pathol. 2008, 21, 639-646. [CrossRef]

40. Balch, C.M.; Soong, S.J.; Gershenwald, J.E.; Thompson, J.F.; Reintgen, D.S.; Cascinelli, N.; Urist, M.; McMasters, K.M.; Ross, M.I.; Kirkwood, J.M.; et al. Prognostic factors analysis of 17,600 melanoma patients: Validation of the american joint committee on cancer melanoma staging system. J. Clin. Oncol. 2001, 19, 3622-3634. [CrossRef]

41. Coppé, J.P.; Desprez, P.Y.; Krtolica, A.; Campisi, J. The senescence-associated secretory phenotype: The dark side of tumor suppression. Annu. Rev. Pathol. 2010, 5, 99-118. [CrossRef]

42. Cirri, P.; Chiarugi, P. Cancer associated fibroblasts: The dark side of the coin. Am. J. Cancer Res. 2011, 1, 482-497.

43. Guido, C.; Whitaker-Menezes, D.; Capparelli, C.; Balliet, R.; Lin, Z.; Pestell, R.G.; Howell, A.; Aquila, S.; Andò, S.; Martinez-Outschoorn, U.; et al. Metabolic reprogramming of cancer-associated fibroblasts by TGF- $\beta$ drives tumor growth: Connecting TGF- $\beta$ signaling with "warburg-like" cancer metabolism and L-lactate production. Cell. Cycle 2012, 11, 3019-3035. [CrossRef]

44. Micke, P.; Ostman, A. Exploring the tumour environment: Cancer-associated fibroblasts as targets in cancer therapy. Expert Opin. Ther. Targets 2005, 9, 1217-1233. [CrossRef]

45. Bellei, B.; Picardo, M. Premature cell senescence in human skin: Dual face in chronic acquired pigmentary disorders. Ageing Res. Rev. 2020, 57, 100981. [CrossRef]

46. Almeida, F.V.; Douglass, S.M.; Fane, M.E.; Weeraratna, A.T. Bad Company: Microenvironmentally mediated resistance to targeted therapy in melanoma. Pigment Cell. Melanoma Res. 2019, 32, 237-247. [CrossRef]

47. Tsang, M.; Quesnel, K.; Vincent, K.; Hutchenreuther, J.; Postovit, L.M.; Leask, A. Insights into fibroblast plasticity: Cellular communication network 2 is required for activation of cancer-associated fibroblasts in a murine model of melanoma. Am. J. Pathol. 2020, 190, 206-221. [CrossRef]

48. Danen, E.H.; de Vries, T.J.; Morandini, R.; Ghanem, G.G.; Ruiter, D.J.; van Muijen, G.N. E-cadherin expression in human melanoma. Melanoma Res. 1996, 6, 127-131. [CrossRef]

49. Hsu, M.Y.; Meier, F.E.; Nesbit, M.; Hsu, J.Y.; Van Belle, P.; Elder, D.E.; Herlyn, M. E-cadherin expression in melanoma cells restores keratinocyte-mediated growth control and down-regulates expression of invasion-related adhesion receptors. Am. J. Pathol. 2000, 156, 1515-1525. [CrossRef]

50. Silye, R.; Karayiannakis, A.J.; Syrigos, K.N.; Poole, S.; van Noorden, S.; Batchelor, W.; Regele, H.; Sega, W.; Boesmueller, H.; Krausz, T.; et al. E-cadherin/catenin complex in benign and malignant melanocytic lesions. J. Pathol. 1998, 186, 350-355. [CrossRef]

51. Hsu, M.Y.; Meier, F.; Herlyn, M. Melanoma development and progression: A conspiracy between tumor and host. Differentiation 2002, 70, 522-536. [CrossRef] [PubMed]

52. Sanders, D.S.; Blessing, K.; Hassan, G.A.; Bruton, R.; Marsden, J.R.; Jankowski, J. Alterations in cadherin and catenin expression during the biological progression of melanocytic tumours. Mol. Pathol. 1999, 52, 151-157. [CrossRef] [PubMed]

53. Haass, N.K.; Smalley, K.S.; Li, L.; Herlyn, M. Adhesion, migration and communication in melanocytes and melanoma. Pigment Cell Res. 2005, 18, 150-159. [CrossRef] [PubMed]

54. Tang, A.; Eller, M.S.; Hara, M.; Yaar, M.; Hirohashi, S.; Gilchrest, B.A. E-cadherin is the major mediator of human melanocyte adhesion to keratinocytes in vitro. J. Cell. Sci. 1994, 107, 983-992.

55. Li, G.; Satyamoorthy, K.; Herlyn, M. N-cadherin-mediated intercellular interactions promote survival and migration of melanoma cells. Cancer Res. 2001, 61, 3819-3825.

56. Li, G.; Satyamoorthy, K.; Meier, F.; Berking, C.; Bogenrieder, T.; Herlyn, M. Function and regulation of melanoma-stromal fibroblast interactions: When seeds meet soil. Oncogene 2003, 22, 3162-3171. [CrossRef] 
57. Kuphal, S.; Poser, I.; Jobin, C.; Hellerbrand, C.; Bosserhoff, A.K. Loss of E-cadherin leads to upregulation of NFkappaB activity in malignant melanoma. Oncogene 2004, 23, 8509-8519. [CrossRef]

58. McGary, E.C.; Lev, D.C.; Bar-Eli, M. Cellular adhesion pathways and metastatic potential of human melanoma. Cancer Biol. Ther. 2002, 1, 459-465. [CrossRef]

59. Hazan, R.B.; Phillips, G.R.; Qiao, R.F.; Norton, L.; Aaronson, S.A. Exogenous expression of N-cadherin in breast cancer cells induces cell migration, invasion, and metastasis. J. Cell Biol. 2000, 148, 779-790. [CrossRef]

60. Raposo, G.; Marks, M.S. Melanosomes-dark organelles enlighten endosomal membrane transport. Nat. Rev. Mol. Cell Biol. 2007, 8, 786-797. [CrossRef]

61. Dror, S.; Sander, L.; Schwartz, H.; Sheinboim, D.; Barzilai, A.; Dishon, Y.; Apcher, S.; Golan, T.; Greenberger, S.; Barshack, I.; et al. Melanoma miRNA trafficking controls tumour primary niche formation. Nat. Cell Biol. 2016, 18, 1006-1017. [CrossRef] [PubMed]

62. Anderberg, C.; Pietras, K. On the origin of cancer-associated fibroblasts. Cell. Cycle 2009, 8, 1461-1462. [CrossRef] [PubMed]

63. Hauge, A.; Rofstad, E.K. Antifibrotic therapy to normalize the tumor microenvironment. J. Transl. Med. 2020, 18, 207-218. [CrossRef]

64. Otranto, M.; Sarrazy, V.; Bonté, F.; Hinz, B.; Gabbiani, G.; Desmoulière, A. The role of the myofibroblast in tumor stroma remodeling. Cell. Adh. Migr. 2012, 6, 203-219. [CrossRef] [PubMed]

65. Shimoda, M.; Mellody, K.T.; Orimo, A. Carcinoma-associated fibroblasts are a rate-limiting determinant for tumour progression. Semin. Cell Dev. Biol. 2010, 21, 19-25. [CrossRef] [PubMed]

66. Érsek, B.; Silló, P.; Cakir, U.; Molnár, V.; Bencsik, A.; Mayer, B.; Mezey, E.; Kárpáti, S.; Pós, Z.; Németh, K. Melanoma-associated fibroblasts impair CD8+ T cell function and modify expression of immune checkpoint regulators via increased arginase activity. Cell Mol. Life Sci. 2020, 77, 1-13.

67. Zhou, L.; Yang, K.; Andl, T.; Wickett, R.R.; Zhang, Y. Perspective of targeting cancer-associated fibroblasts in melanoma. J. Cancer 2015, 6, 717-726. [CrossRef]

68. García-Silva, S.; Peinado, H. Melanosomes foster a tumour niche by activating CAFs. Nat. Cell Biol. 2016, 18, 911-913. [CrossRef]

69. Gieniec, K.A.; Butler, L.M.; Worthley, D.L.; Woods, S.L. Cancer-associated fibroblasts-heroes or villains? Br. J. Cancer 2019, 121, 293-302. [CrossRef]

70. Zhou, L.; Yang, K.; Randall Wickett, R.; Zhang, Y. Dermal fibroblasts induce cell cycle arrest and block epithelial-mesenchymal transition to inhibit the early stage melanoma development. Cancer Med. 2016, 5, 1566-1579. [CrossRef]

71. Cornil, I.; Theodorescu, D.; Man, S.; Herlyn, M.; Jambrosic, J.; Kerbel, R.S. Fibroblast cell interactions with human melanoma cells affect tumor cell growth as a function of tumor progression. Proc. Natl. Acad. Sci. USA 1991, 88, 6028-6032. [CrossRef] [PubMed]

72. Zhou, L.; Yang, K.; Wickett, R.R.; Kadekaro, A.L.; Zhang, Y. Targeted deactivation of cancer-associated fibroblasts by $\beta$-catenin ablation suppresses melanoma growth. Tumour Biol. 2016, 37, 14235-14248. [CrossRef] [PubMed]

73. Madar, S.; Brosh, R.; Buganim, Y.; Ezra, O.; Goldstein, I.; Solomon, H.; Kogan, I.; Goldfinger, N.; Klocker, H.; Rotter, V. Modulated expression of WFDC1 during carcinogenesis and cellular senescence. Carcinogenesis 2009, 30, 20-27. [CrossRef] [PubMed]

74. Liberato, T.; Pessotti, D.S.; Fukushima, I.; Kitano, E.S.; Serrano, S.M.T.; Zelanis, A. Signatures of protein expression revealed by secretome analyses of cancer associated fibroblasts and melanoma cell lines. J. Proteomics 2018, 174, 1-8. [CrossRef] [PubMed]

75. Pessotti, D.S.; Andrade-Silva, D.; Serrano, S.M.T.; Zelanis, A. Heterotypic signaling between dermal fibroblasts and melanoma cells induces phenotypic plasticity and proteome rearrangement in malignant cells. Biochim. Biophys. Acta Proteins Proteom. 2020, 1868, 140525. [CrossRef] [PubMed]

76. Li, L.; Dragulev, B.; Zigrino, P.; Mauch, C.; Fox, J.W. The invasive potential of human melanoma cell lines correlates with their ability to alter fibroblast gene expression in vitro and the stromal microenvironment in vivo. Int. J. Cancer 2009, 125, 1796-1804. [CrossRef]

77. Lu, C.; Vickers, M.F.; Kerbel, R.S. Interleukin 6: A fibroblast-derived growth inhibitor of human melanoma cells from early but not advanced stages of tumor progression. Proc. Natl. Acad. Sci. USA 1992, 89, 9215-9219. [CrossRef] 
78. Jobe, N.P.; Rösel, D.; Dvořánková, B.; Kodet, O.; Lacina, L.; Mateu, R.; Smetana, K.; Brábek, J. Simultaneous blocking of IL-6 and IL-8 is sufficient to fully inhibit CAF-induced human melanoma cell invasiveness. Histochem. Cell Biol. 2016, 146, 205-217. [CrossRef]

79. Balsamo, M.; Scordamaglia, F.; Pietra, G.; Manzini, C.; Cantoni, C.; Boitano, M.; Queirolo, P.; Vermi, W.; Facchetti, F.; Moretta, A.; et al. Melanoma-associated fibroblasts modulate NK cell phenotype and antitumor cytotoxicity. Proc. Natl. Acad. Sci. USA 2009, 106, 20847-20852. [CrossRef]

80. Goldstein, L.J.; Chen, H.; Bauer, R.J.; Bauer, S.M.; Velazquez, O.C. Normal human fibroblasts enable melanoma cells to induce angiogenesis in type I collagen. Surgery 2005, 138, 439-449. [CrossRef]

81. Rhim, A.D.; Oberstein, P.E.; Thomas, D.H.; Mirek, E.T.; Palermo, C.F.; Sastra, S.A.; Dekleva, E.N.; Saunders, T.; Becerra, C.P.; Tattersall, I.W.; et al. Stromal elements act to restrain, rather than support, pancreatic ductal adenocarcinoma. Cancer Cell 2014, 25, 735-747. [CrossRef] [PubMed]

82. Özdemir, B.C.; Pentcheva-Hoang, T.; Carstens, J.L.; Zheng, X.; Wu, C.C.; Simpson, T.R.; Laklai, H.; Sugimoto, H.; Kahlert, C.; Novitskiy, S.V.; et al. Depletion of carcinoma-associated fibroblasts and fibrosis induces immunosuppression and accelerates pancreas cancer with reduced survival. Cancer Cell 2015, 28, 831-833. [CrossRef] [PubMed]

83. Kikuchi, A.; Yamamoto, H.; Sato, A.; Matsumoto, S. New insights into the mechanism of Wnt signaling pathway activation. Int. Rev. Cell. Mol. Biol. 2011, 291, 21-71. [PubMed]

84. van Amerongen, R.; Nusse, R. Towards an integrated view of Wnt signaling in development. Development 2009, 136, 3205-3214. [CrossRef]

85. MacDonald, B.T.; Tamai, K.; He, X. Wnt/beta-catenin signaling: Components, mechanisms, and diseases. Dev. Cell. 2009, 17, 9-26. [CrossRef]

86. Gloushankova, N.A.; Rubtsova, S.N.; Zhitnyak, I.Y. Cadherin-mediated cell-cell interactions in normal and cancer cells. Tissue Barriers 2017, 5, e1356900. [CrossRef]

87. Tafrihi, M.; Nakhaei Sistani, R. E-cadherin/ $\beta$-catenin complex: A target for anticancer and antimetastasis plants/plant-derived compounds. Nutr. Cancer 2017, 69, 702-722. [CrossRef]

88. Behrens, J.; Jerchow, B.A.; Würtele, M.; Grimm, J.; Asbrand, C.; Wirtz, R.; Kühl, M.; Wedlich, D.; Birchmeier, W. Functional interaction of an axin homolog, conductin, with beta-catenin, APC, and GSK3beta. Science 1998, 280, 596-599. [CrossRef]

89. Hrckulak, D.; Kolar, M.; Strnad, H.; Korinek, V. TCF/LEF transcription factors: An update from the internet resources. Cancers 2016, 8, 70. [CrossRef]

90. Dorsky, R.I.; Raible, D.W.; Moon, R.T. Direct regulation of nacre, a zebrafish MITF homolog required for pigment cell formation, by the Wnt pathway. Genes Dev. 2000, 14, 158-162.

91. Schepsky, A.; Bruser, K.; Gunnarsson, G.J.; Goodall, J.; Hallsson, J.H.; Goding, C.R.; Steingrimsson, E.; Hecht, A. The microphthalmia-associated transcription factor Mitf interacts with beta-catenin to determine target gene expression. Mol. Cell. Biol. 2006, 26, 8914-8927. [CrossRef] [PubMed]

92. Saito, H.; Yasumoto, K.; Takeda, K.; Takahashi, K.; Yamamoto, H.; Shibahara, S. Microphthalmia-associated transcription factor in the Wnt signaling pathway. Pigment Cell Res. 2003, 16, 261-265. [CrossRef] [PubMed]

93. Larue, L.; Delmas, V. The WNT/beta-catenin pathway in melanoma. Front. Biosci. 2006, 11, 733-742. [CrossRef] [PubMed]

94. Bellei, B.; Flori, E.; Izzo, E.; Maresca, V.; Picardo, M. GSK3beta inhibition promotes melanogenesis in mouse B16 melanoma cells and normal human melanocytes. Cell. Signal. 2008, 20, 1750-1761. [CrossRef] [PubMed]

95. Bellei, B.; Pitisci, A.; Catricalà, C.; Larue, L.; Picardo, M. Wnt/ $\beta$-catenin signaling is stimulated by $\alpha$-melanocyte-stimulating hormone in melanoma and melanocyte cells: Implication in cell differentiation. Pigment Cell. Melanoma Res. 2011, 24, 309-325. [CrossRef]

96. Larue, L.; Kumasaka, M.; Goding, C.R. Beta-catenin in the melanocyte lineage. Pigment Cell Res. 2003, 16, 312-317. [CrossRef]

97. Hari, L.; Brault, V.; Kléber, M.; Lee, H.Y.; Ille, F.; Leimeroth, R.; Paratore, C.; Suter, U.; Kemler, R.; Sommer, L. Lineage-specific requirements of beta-catenin in neural crest development. J. Cell Biol. 2002, 159, 867-880. [CrossRef]

98. De Melker, A.A.; Desban, N.; Duband, J.L. Cellular localization and signaling activity of beta-catenin in migrating neural crest cells. Dev. Dyn. 2004, 230, 708-726. [CrossRef] 
99. Yamada, T.; Hasegawa, S.; Inoue, Y.; Date, Y.; Yamamoto, N.; Mizutani, H.; Nakata, S.; Matsunaga, K.; Akamatsu, H. Wnt/ $\beta$-catenin and kit signaling sequentially regulate melanocyte stem cell differentiation in UVB-induced epidermal pigmentation. J. Investig. Dermatol. 2013, 133, 2753-2762. [CrossRef]

100. Goldstein, N.B.; Koster, M.I.; Jones, K.L.; Gao, B.; Hoaglin, L.G.; Robinson, S.E.; Wright, M.J.; Birlea, S.I.; Luman, A.; Lambert, K.A.; et al. Repigmentation of human vitiligo skin by NBUVB is controlled by transcription of GLI1 and activation of the $\beta$-catenin pathway in the hair follicle bulge stem cells. J. Investig. Dermatol. 2018, 138, 657-668. [CrossRef]

101. Bellei, B.; Pacchiarotti, A.; Perez, M.; Faraggiana, T. Frequent beta-catenin overexpression without exon 3 mutation in cutaneous lymphomas. Mod. Pathol. 2004, 17, 1275-1281. [CrossRef] [PubMed]

102. Clevers, H. Wnt/beta-catenin signaling in development and disease. Cell 2006, 127, 469-480. [CrossRef] [PubMed]

103. Ring, A.; Kim, Y.M.; Kahn, M. Wnt/catenin signaling in adult stem cell physiology and disease. Stem Cell. Rev. Rep. 2014, 10, 512-525. [CrossRef] [PubMed]

104. Galluzzi, L.; Spranger, S.; Fuchs, E.; López-Soto, A. WNT signaling in cancer immunosurveillance. Trends Cell Biol. 2019, 29, 44-65. [CrossRef] [PubMed]

105. Sinnberg, T.; Menzel, M.; Ewerth, D.; Sauer, B.; Schwarz, M.; Schaller, M.; Garbe, C.; Schittek, B. B-catenin signaling increases during melanoma progression and promotes tumor cell survival and chemoresistance. PLoS ONE 2011, 6, e23429. [CrossRef] [PubMed]

106. Rimm, D.L.; Caca, K.; Hu, G.; Harrison, F.B.; Fearon, E.R. Frequent nuclear/cytoplasmic localization of beta-catenin without exon 3 mutations in malignant melanoma. Am. J. Pathol. 1999, 154, 325-329. [CrossRef]

107. Omholt, K.; Platz, A.; Ringborg, U.; Hansson, J. Cytoplasmic and nuclear accumulation of beta-catenin is rarely caused by CTNNB1 exon 3 mutations in cutaneous malignant melanoma. Int. J. Cancer 2001, 92, 839-842. [CrossRef]

108. Demunter, A.; Libbrecht, L.; Degreef, H.; De Wolf-Peeters, C.; van den Oord, J.J. Loss of membranous expression of beta-catenin is associated with tumor progression in cutaneous melanoma and rarely caused by exon 3 mutations. Mod. Pathol. 2002, 15, 454-461. [CrossRef]

109. Worm, J.; Christensen, C.; Grønbaek, K.; Tulchinsky, E.; Guldberg, P. Genetic and epigenetic alterations of the APC gene in malignant melanoma. Oncogene 2004, 23, 5215-5226. [CrossRef]

110. Reifenberger, J.; Knobbe, C.B.; Wolter, M.; Blaschke, B.; Schulte, K.W.; Pietsch, T.; Ruzicka, T.; Reifenberger, G. Molecular genetic analysis of malignant melanomas for aberrations of the WNT signaling pathway genes CTNNB1, APC, ICAT and BTRC. Int. J. Cancer 2002, 100, 549-556. [CrossRef]

111. Castiglia, D.; Bernardini, S.; Alvino, E.; Pagani, E.; De Luca, N.; Falcinelli, S.; Pacchiarotti, A.; Bonmassar, E.; Zambruno, G.; D'Atri, S. Concomitant activation of Wnt pathway and loss of mismatch repair function in human melanoma. Genes Chromosomes Cancer 2008, 47, 614-624. [CrossRef] [PubMed]

112. Rubinfeld, B.; Robbins, P.; El-Gamil, M.; Albert, I.; Porfiri, E.; Polakis, P. Stabilization of beta-catenin by genetic defects in melanoma cell lines. Science 1997, 275, 1790-1792. [CrossRef] [PubMed]

113. Kuphal, S.; Lodermeyer, S.; Bataille, F.; Schuierer, M.; Hoang, B.H.; Bosserhoff, A.K. Expression of dickkopf genes is strongly reduced in malignant melanoma. Oncogene 2006, 25, 5027-5036. [CrossRef] [PubMed]

114. Huynh, K.T.; Takei, Y.; Kuo, C.; Scolyer, R.A.; Murali, R.; Chong, K.; Takeshima, L.; Sim, M.S.; Morton, D.L.; Turner, R.R.; et al. Aberrant hypermethylation in primary tumours and sentinel lymph node metastases in paediatric patients with cutaneous melanoma. Br. J. Dermatol. 2012, 166, 1319-1326. [CrossRef] [PubMed]

115. Massi, D.; Romano, E.; Rulli, E.; Merelli, B.; Nassini, R.; De Logu, F.; Bieche, I.; Baroni, G.; Cattaneo, L.; Xue, G.; et al. Baseline $\beta$-catenin, programmed death-ligand 1 expression and tumour-infiltrating lymphocytes predict response and poor prognosis in BRAF inhibitor-treated melanoma patients. Eur. J. Cancer 2017, 78, 70-81. [CrossRef]

116. Gajos-Michniewicz, A.; Czyz, M. WNT signaling in melanoma. Int. J. Mol. Sci. 2020, 21, 4852. [CrossRef]

117. Lucero, O.M.; Dawson, D.W.; Moon, R.T.; Chien, A.J. A re-evaluation of the "oncogenic" nature of Wnt/beta-catenin signaling in melanoma and other cancers. Curr. Oncol. Rep. 2010, 12, 314-318. [CrossRef]

118. Larue, L.; Delmas, V. Secrets to developing Wnt-age melanoma revealed. Pigment Cell. Melanoma Res. 2009, 22, 520-521. [CrossRef]

119. Widlund, H.R.; Horstmann, M.A.; Price, E.R.; Cui, J.; Lessnick, S.L.; Wu, M.; He, X.; Fisher, D.E. Beta-Catenin-induced melanoma growth requires the downstream target microphthalmia-associated transcription factor. J. Cell Biol. 2002, 158, 1079-1087. [CrossRef] 
120. Chien, A.J.; Moore, E.C.; Lonsdorf, A.S.; Kulikauskas, R.M.; Rothberg, B.G.; Berger, A.J.; Major, M.B.; Hwang, S.T.; Rimm, D.L.; Moon, R.T. Activated Wnt/beta-catenin signaling in melanoma is associated with decreased proliferation in patient tumors and a murine melanoma model. Proc. Natl. Acad. Sci. USA 2009, 106, 1193-1198. [CrossRef]

121. Arozarena, I.; Bischof, H.; Gilby, D.; Belloni, B.; Dummer, R.; Wellbrock, C. In melanoma, beta-catenin is a suppressor of invasion. Oncogene 2011, 30, 4531-4543. [CrossRef] [PubMed]

122. Gallagher, S.J.; Rambow, F.; Kumasaka, M.; Champeval, D.; Bellacosa, A.; Delmas, V.; Larue, L. Beta-catenin inhibits melanocyte migration but induces melanoma metastasis. Oncogene 2013, 32, 2230-2238. [CrossRef] [PubMed]

123. Bachmann, I.M.; Straume, O.; Puntervoll, H.E.; Kalvenes, M.B.; Akslen, L.A. Importance of p-cadherin, beta-catenin, and Wnt5a/frizzled for progression of melanocytic tumors and prognosis in cutaneous melanoma. Clin. Cancer Res. 2005, 11, 8606-8614. [CrossRef] [PubMed]

124. Kageshita, T.; Hamby, C.V.; Ishihara, T.; Matsumoto, K.; Saida, T.; Ono, T. Loss of beta-catenin expression associated with disease progression in malignant melanoma. Br. J. Dermatol. 2001, 145, 210-216. [CrossRef]

125. De la Fouchardière, A.; Caillot, C.; Jacquemus, J.; Durieux, E.; Houlier, A.; Haddad, V.; Pissaloux, D. B-catenin nuclear expression discriminates deep penetrating nevi from other cutaneous melanocytic tumors. Virchows Arch. 2019, 474, 539-550. [CrossRef]

126. Hoek, K.S.; Eichhoff, O.M.; Schlegel, N.C.; Döbbeling, U.; Kobert, N.; Schaerer, L.; Hemmi, S.; Dummer, R. In vivo switching of human melanoma cells between proliferative and invasive states. Cancer Res. 2008, 68, 650-656. [CrossRef]

127. Eichhoff, O.M.; Zipser, M.C.; Xu, M.; Weeraratna, A.T.; Mihic, D.; Dummer, R.; Hoek, K.S. The immunohistochemistry of invasive and proliferative phenotype switching in melanoma: A case report. Melanoma Res. 2010, 20, 349-355. [CrossRef]

128. Kovacs, D.; Migliano, E.; Muscardin, L.; Silipo, V.; Catricalà, C.; Picardo, M.; Bellei, B. The role of Wnt/ $\beta$-catenin signaling pathway in melanoma epithelial-to-mesenchymal-like switching: Evidences from patients-derived cell lines. Oncotarget 2016, 7, 43295-43314. [CrossRef]

129. Webster, M.R.; Kugel, C.H., III; Weeraratna, A.T. The Wnts of change: How Wnts regulate phenotype switching in melanoma. Biochim. Biophys. Acta 2015, 1856, 244-251. [CrossRef]

130. Spranger, S.; Bao, R.; Gajewski, T.F. Melanoma-intrinsic $\beta$-catenin signalling prevents anti-tumour immunity. Nature 2015, 523, 231-235. [CrossRef]

131. Nsengimana, J.; Laye, J.; Filia, A.; O’Shea, S.; Muralidhar, S.; Poźniak, J.; Droop, A.; Chan, M.; Walker, C.; Parkinson, L.; et al. B-catenin-mediated immune evasion pathway frequently operates in primary cutaneous melanomas. J. Clin. Investig. 2018, 128, 2048-2063. [CrossRef] [PubMed]

132. Li, X.; Xiang, Y.; Li, F.; Yin, C.; Li, B.; Ke, X. WNT/ $\beta$-catenin signaling pathway regulating T cell-inflammation in the tumor microenvironment. Front. Immunol. 2019, 10, 2293. [CrossRef] [PubMed]

133. Luke, J.J.; Bao, R.; Sweis, R.F.; Spranger, S.; Gajewski, T.F. WNT/ $\beta$-catenin pathway activation correlates with immune exclusion across human cancers. Clin. Cancer Res. 2019, 25, 3074-3083. [CrossRef] [PubMed]

134. Ganesh, S.; Shui, X.; Craig, K.P.; Park, J.; Wang, W.; Brown, B.D.; Abrams, M.T. RNAi-mediated $\beta$-catenin inhibition promotes $\mathrm{T}$ cell infiltration and antitumor activity in combination with immune checkpoint blockade. Mol. Ther. 2018, 26, 2567-2579. [CrossRef]

135. Biechele, T.L.; Kulikauskas, R.M.; Toroni, R.A.; Lucero, O.M.; Swift, R.D.; James, R.G.; Robin, N.C.; Dawson, D.W.; Moon, R.T.; Chien, A.J. Wnt/ $\beta$-catenin signaling and AXIN1 regulate apoptosis triggered by inhibition of the mutant kinase BRAFV600E in human melanoma. Sci. Signal. 2012, 5, ra3. [CrossRef]

136. Conrad, W.H.; Swift, R.D.; Biechele, T.L.; Kulikauskas, R.M.; Moon, R.T.; Chien, A.J. Regulating the response to targeted MEK inhibition in melanoma: Enhancing apoptosis in NRAS- and BRAF-mutant melanoma cells with Wnt/ $\beta$-catenin activation. Cell. Cycle 2012, 11, 3724-3730. [CrossRef]

137. Chien, A.J.; Haydu, L.E.; Biechele, T.L.; Kulikauskas, R.M.; Rizos, H.; Kefford, R.F.; Scolyer, R.A.; Moon, R.T.; Long, G.V. Targeted BRAF inhibition impacts survival in melanoma patients with high levels of Wnt/ $\beta$-catenin signaling. PLoS ONE 2014, 9, e94748. [CrossRef]

138. Fodde, R.; Brabletz, T. Wnt/beta-catenin signaling in cancer stemness and malignant behavior. Curr. Opin. Cell Biol. 2007, 19, 150-158. [CrossRef] 
139. Unterleuthner, D.; Neuhold, P.; Schwarz, K.; Janker, L.; Neuditschko, B.; Nivarthi, H.; Crncec, I.; Kramer, N.; Unger, C.; Hengstschläger, M.; et al. Cancer-associated fibroblast-derived WNT2 increases tumor angiogenesis in colon cancer. Angiogenesis 2020, 23, 159-177. [CrossRef]

140. Kramer, N.; Schmöllerl, J.; Unger, C.; Nivarthi, H.; Rudisch, A.; Unterleuthner, D.; Scherzer, M.; Riedl, A.; Artaker, M.; Crncec, I.; et al. Autocrine WNT2 signaling in fibroblasts promotes colorectal cancer progression. Oncogene 2017, 36, 5460-5472. [CrossRef]

141. Rasola, A.; Fassetta, M.; De Bacco, F.; D'Alessandro, L.; Gramaglia, D.; Di Renzo, M.F.; Comoglio, P.M. A positive feedback loop between hepatocyte growth factor receptor and beta-catenin sustains colorectal cancer cell invasive growth. Oncogene 2007, 26, 1078-1087. [CrossRef] [PubMed]

142. Yang, L.; Lin, C.; Liu, Z.R. P68 RNA helicase mediates PDGF-induced epithelial mesenchymal transition by displacing axin from beta-catenin. Cell 2006, 127, 139-155. [CrossRef]

143. Kaur, A.; Webster, M.R.; Marchbank, K.; Behera, R.; Ndoye, A.; Kugel, C.H., III; Dang, V.M.; Appleton, J.; O'Connell, M.P.; Cheng, P.; et al. SFRP2 in the aged microenvironment drives melanoma metastasis and therapy resistance. Nature 2016, 532, 250-254. [CrossRef] [PubMed]

144. Bittner, M.; Meltzer, P.; Chen, Y.; Jiang, Y.; Seftor, E.; Hendrix, M.; Radmacher, M.; Simon, R.; Yakhini, Z.; Ben-Dor, A.; et al. Molecular classification of cutaneous malignant melanoma by gene expression profiling. Nature 2000, 406, 536-540. [CrossRef] [PubMed]

145. Weeraratna, A.T.; Jiang, Y.; Hostetter, G.; Rosenblatt, K.; Duray, P.; Bittner, M.; Trent, J.M. Wnt5a signaling directly affects cell motility and invasion of metastatic melanoma. Cancer Cell 2002, 1, 279-288. [CrossRef]

146. Pham, K.; Milovanovic, T.; Barr, R.J.; Truong, T.; Holcombe, R.F. Wnt ligand expression in malignant melanoma: Pilot study indicating correlation with histopathological features. Mol. Pathol. 2003, 56, $280-285$. [CrossRef] [PubMed]

147. Yang, Y.; Ye, Y.C.; Chen, Y.; Zhao, J.L.; Gao, C.C.; Han, H.; Liu, W.C.; Qin, H.Y. Crosstalk between hepatic tumor cells and macrophages via Wnt/ $\beta$-catenin signaling promotes M2-like macrophage polarization and reinforces tumor malignant behaviors. Cell. Death Dis. 2018, 9, 793. [CrossRef]

148. Katoh, M. Multi-layered prevention and treatment of chronic inflammation, organ fibrosis and cancer associated with canonical WNT/ $\beta$-catenin signaling activation (review). Int. J. Mol. Med. 2018, 42, 713-725. [CrossRef]

149. Baarsma, H.A.; Spanjer, A.I.; Haitsma, G.; Engelbertink, L.H.; Meurs, H.; Jonker, M.R.; Timens, W.; Postma, D.S.; Kerstjens, H.A.; Gosens, R. Activation of WNT/ $\beta$-catenin signaling in pulmonary fibroblasts by TGF- $\beta_{1}$ is increased in chronic obstructive pulmonary disease. PLoS ONE 2011, 6, e25450. [CrossRef]

150. Chilosi, M.; Poletti, V.; Zamò, A.; Lestani, M.; Montagna, L.; Piccoli, P.; Pedron, S.; Bertaso, M.; Scarpa, A.; Murer, B.; et al. Aberrant Wnt/beta-catenin pathway activation in idiopathic pulmonary fibrosis. Am. J. Pathol. 2003, 162, 1495-1502. [CrossRef]

151. Cheon, H.; Boyle, D.L.; Firestein, G.S. Wnt1 inducible signaling pathway protein-3 regulation and microsatellite structure in arthritis. J. Rheumatol. 2004, 31, 2106-2114. [PubMed]

152. Cheon, S.; Poon, R.; Yu, C.; Khoury, M.; Shenker, R.; Fish, J.; Alman, B.A. Prolonged beta-catenin stabilization and Tcf-dependent transcriptional activation in hyperplastic cutaneous wounds. Lab. Investig. 2005, 85, 416-425. [CrossRef] [PubMed]

153. Akhmetshina, A.; Palumbo, K.; Dees, C.; Bergmann, C.; Venalis, P.; Zerr, P.; Horn, A.; Kireva, T.; Beyer, C.; Zwerina, J.; et al. Activation of canonical Wnt signalling is required for TGF- $\beta$-mediated fibrosis. Nat. Commun. 2012, 3, 735. [CrossRef] [PubMed]

154. Jahoda, C.A.B.; Gilmore, A.C. What lies beneath: Wnt/ $\beta$-catenin signaling and cell fate in the lower dermis. J. Investig. Dermatol. 2016, 136, 1084-1087. [CrossRef] [PubMed]

155. Mastrogiannaki, M.; Lichtenberger, B.M.; Reimer, A.; Collins, C.A.; Driskell, R.R.; Watt, F.M. B-catenin stabilization in skin fibroblasts causes fibrotic lesions by preventing adipocyte differentiation of the reticular dermis. J. Investig. Dermatol. 2016, 136, 1130-1142. [CrossRef] [PubMed]

156. Liu, T.; Zhou, L.; Yang, K.; Iwasawa, K.; Kadekaro, A.L.; Takebe, T.; Andl, T.; Zhang, Y. The $\beta$-catenin/YAP signaling axis is a key regulator of melanoma-associated fibroblasts. Signal. Transduct. Target. Ther. 2019, 4, 63-78. [CrossRef]

157. Zhou, L.; Yang, K.; Dunaway, S.; Abdel-Malek, Z.; Andl, T.; Kadekaro, A.L.; Zhang, Y. Suppression of MAPK signaling in BRAF-activated PTEN-deficient melanoma by blocking $\beta$-catenin signaling in cancer-associated fibroblasts. Pigment Cell. Melanoma Res. 2018, 31, 297-307. [CrossRef] 
158. Shao, H.; Kong, R.; Ferrari, M.L.; Radtke, F.; Capobianco, A.J.; Liu, Z.J. Notch1 pathway activity determines the regulatory role of cancer-associated fibroblasts in melanoma growth and invasion. PLOS ONE 2015, 10, e0142815. [CrossRef]

159. Du, J.; Zu, Y.; Li, J.; Du, S.; Xu, Y.; Zhang, L.; Jiang, L.; Wang, Z.; Chien, S.; Yang, C. Extracellular matrix stiffness dictates Wnt expression through integrin pathway. Sci. Rep. 2016, 6, 20395. [CrossRef]

160. Yeung, Y.T.; Guerrero-Castilla, A.; Cano, M.; Muñoz, M.F.; Ayala, A.; Argüelles, S. Dysregulation of the hippo pathway signaling in aging and cancer. Pharmacol. Res. 2019, 143, 151-165. [CrossRef]

161. Yu, F.X.; Zhao, B.; Guan, K.L. Hippo pathway in organ size control, tissue homeostasis, and cancer. Cell 2015, 163, 811-828. [CrossRef] [PubMed]

162. Harvey, K.F.; Zhang, X.; Thomas, D.M. The hippo pathway and human cancer. Nat. Rev. Cancer 2013, 13, 246-257. [CrossRef] [PubMed]

163. Zhang, X.; Tang, J.Z.; Vergara, I.A.; Zhang, Y.; Szeto, P.; Yang, L.; Mintoff, C.; Colebatch, A.; McIntosh, L.; Mitchell, K.A.; et al. Somatic hypermutation of the YAP oncogene in a human cutaneous melanoma. Mol. Cancer Res. 2019, 17, 1435-1449. [CrossRef] [PubMed]

164. Menzel, M.; Meckbach, D.; Weide, B.; Toussaint, N.C.; Schilbach, K.; Noor, S.; Eigentler, T.; Ikenberg, K.; Busch, C.; Quintanilla-Martinez, L.; et al. In melanoma, hippo signaling is affected by copy number alterations and YAP1 overexpression impairs patient survival. Pigment Cell. Melanoma Res. 2014, 27, 671-673. [CrossRef] [PubMed]

165. Sarmasti Emami, S.; Zhang, D.; Yang, X. Interaction of the hippo pathway and phosphatases in tumorigenesis. Cancers 2020, 12, 2438. [CrossRef] [PubMed]

166. Dey, A.; Varelas, X.; Guan, K.L. Targeting the hippo pathway in cancer, fibrosis, wound healing and regenerative medicine. Nat. Rev. Drug Discov. 2020, 19, 480-494. [CrossRef]

167. Huh, H.D.; Kim, D.H.; Jeong, H.S.; Park, H.W. Regulation of TEAD transcription factors in cancer biology. Cells 2019, 8, 600. [CrossRef]

168. Kim, M.K.; Jang, J.W.; Bae, S.C. DNA binding partners of YAP/TAZ. BMB Rep. 2018, 51, 126-133. [CrossRef]

169. Corvaisier, M.; Bauzone, M.; Corfiotti, F.; Renaud, F.; El Amrani, M.; Monté, D.; Truant, S.; Leteurtre, E.; Formstecher, P.; Van Seuningen, I.; et al. Regulation of cellular quiescence by YAP/TAZ and cyclin E1 in colon cancer cells: Implication in chemoresistance and cancer relapse. Oncotarget 2016, 7, 56699-56712. [CrossRef]

170. Perez, D.E.; Henle, A.M.; Amsterdam, A.; Hagen, H.R.; Lees, J.A. Uveal melanoma driver mutations in GNAQ/11 yield numerous changes in melanocyte biology. Pigment Cell. Melanoma Res. 2018, 31, 604-613. [CrossRef]

171. Lyubasyuk, V.; Ouyang, H.; Yu, F.X.; Guan, K.L.; Zhang, K. YAP inhibition blocks uveal melanogenesis driven by GNAQ Or GNA11 mutations. Mol. Cell. Oncol. 2014, 2, e970957. [CrossRef] [PubMed]

172. Javelaud, D.; Alexaki, V.I.; Pierrat, M.J.; Hoek, K.S.; Dennler, S.; Van Kempen, L.; Bertolotto, C.; Ballotti, R.; Saule, S.; Delmas, V.; et al. GLI2 and M-MITF transcription factors control exclusive gene expression programs and inversely regulate invasion in human melanoma cells. Pigment Cell. Melanoma Res. 2011, 24, 932-943. [CrossRef] [PubMed]

173. Zhang, X.; Yang, L.; Szeto, P.; Abali, G.K.; Zhang, Y.; Kulkarni, A.; Amarasinghe, K.; Li, J.; Vergara, I.A.; Molania, R.; et al. The hippo pathway oncoprotein YAP promotes melanoma cell invasion and spontaneous metastasis. Oncogene 2020, 39, 5267-5281. [CrossRef]

174. Nallet-Staub, F.; Marsaud, V.; Li, L.; Gilbert, C.; Dodier, S.; Bataille, V.; Sudol, M.; Herlyn, M.; Mauviel, A. Pro-invasive activity of the hippo pathway effectors YAP and TAZ in cutaneous melanoma. J. Investig. Dermatol. 2014, 134, 123-132. [CrossRef] [PubMed]

175. Kim, N.G.; Koh, E.; Chen, X.; Gumbiner, B.M. E-cadherin mediates contact inhibition of proliferation through hippo signaling-pathway components. Proc. Natl. Acad. Sci. USA 2011, 108, 11930-11935. [CrossRef] [PubMed]

176. Azzolin, L.; Zanconato, F.; Bresolin, S.; Forcato, M.; Basso, G.; Bicciato, S.; Cordenonsi, M.; Piccolo, S. Role of TAZ as mediator of Wnt signaling. Cell 2012, 151, 1443-1456. [CrossRef]

177. Azzolin, L.; Panciera, T.; Soligo, S.; Enzo, E.; Bicciato, S.; Dupont, S.; Bresolin, S.; Frasson, C.; Basso, G.; Guzzardo, V.; et al. YAP/TAZ incorporation in the $\beta$-catenin destruction complex orchestrates the Wnt response. Cell 2014, 158, 157-170. [CrossRef]

178. Imajo, M.; Miyatake, K.; Iimura, A.; Miyamoto, A.; Nishida, E. A molecular mechanism that links hippo signalling to the inhibition of Wnt/ $\beta$-catenin signalling. EMBO J. 2012, 31, 1109-1122. [CrossRef] 
179. Kim, M.; Jho, E.H. Cross-talk between Wnt/ $\beta$-catenin and hippo signaling pathways: A brief review. BMB Rep. 2014, 47, 540-545. [CrossRef]

180. Johannessen, C.M.; Johnson, L.A.; Piccioni, F.; Townes, A.; Frederick, D.T.; Donahue, M.K.; Narayan, R.; Flaherty, K.T.; Wargo, J.A.; Root, D.E.; et al. A melanocyte lineage program confers resistance to MAP kinase pathway inhibition. Nature 2013, 504, 138-142. [CrossRef]

181. Kim, M.H.; Kim, C.G.; Kim, S.K.; Shin, S.J.; Choe, E.A.; Park, S.H.; Shin, E.C.; Kim, J. YAP-induced PD-L1 expression drives immune evasion in BRAFi-resistant melanoma. Cancer Immunol. Res. 2018, 6, 255-266. [CrossRef] [PubMed]

182. Moya, I.M.; Castaldo, S.A.; Van den Mooter, L.; Soheily, S.; Sansores-Garcia, L.; Jacobs, J.; Mannaerts, I.; Xie, J.; Verboven, E.; Hillen, H.; et al. Peritumoral activation of the hippo pathway effectors YAP and TAZ suppresses liver cancer in mice. Science 2019, 366, 1029-1034. [CrossRef] [PubMed]

183. Lawlor, K.; Pérez-Montero, S.; Lima, A.; Rodríguez, T.A. Transcriptional versus metabolic control of cell fitness during cell competition. Semin. Cancer Biol. 2020, 63, 36-43. [CrossRef] [PubMed]

184. Wu, M.Y.; Hill, C.S. Tgf-beta superfamily signaling in embryonic development and homeostasis. Dev. Cell. 2009, 16, 329-343. [CrossRef]

185. Shi, Y.; Massagué, J. Mechanisms of TGF-beta signaling from cell membrane to the nucleus. Cell 2003, 113, 685-700. [CrossRef]

186. Schmierer, B.; Hill, C.S. TGFbeta-SMAD signal transduction: Molecular specificity and functional flexibility. Nat. Rev. Mol. Cell Biol. 2007, 8, 970-982. [CrossRef]

187. Weber, C.E.; Li, N.Y.; Wai, P.Y.; Kuo, P.C. Epithelial-mesenchymal transition, TGF- $\beta$, and osteopontin in wound healing and tissue remodeling after injury. J. Burn Care. Res. 2012, 33, 311-318. [CrossRef]

188. Colak, S.; Ten Dijke, P. Targeting TGF- $\beta$ signaling in cancer. Trends Cancer 2017, 3, 56-71. [CrossRef]

189. De Caestecker, M.P.; Piek, E.; Roberts, A.B. Role of transforming growth factor-beta signaling in cancer. J. Natl. Cancer Inst. 2000, 92, 1388-1402. [CrossRef]

190. Krasagakis, K.; Garbe, C.; Schrier, P.I.; Orfanos, C.E. Paracrine and autocrine regulation of human melanocyte and melanoma cell growth by transforming growth factor beta in vitro. Anticancer Res. 1994, 14, 2565-2571.

191. Rodeck, U.; Bossler, A.; Graeven, U.; Fox, F.E.; Nowell, P.C.; Knabbe, C.; Kari, C. Transforming growth factor beta production and responsiveness in normal human melanocytes and melanoma cells. Cancer Res. 1994, 54, 575-581. [PubMed]

192. Javelaud, D.; Alexaki, V.I.; Mauviel, A. Transforming growth factor-beta in cutaneous melanoma. Pigment Cell Melanoma Res. 2008, 21, 123-132. [CrossRef] [PubMed]

193. Van Belle, P.; Rodeck, U.; Nuamah, I.; Halpern, A.C.; Elder, D.E. Melanoma-associated expression of transforming growth factor-beta isoforms. Am. J. Pathol. 1996, 148, 1887-1894. [PubMed]

194. Reed, J.A.; McNutt, N.S.; Prieto, V.G.; Albino, A.P. Expression of transforming growth factor-beta 2 in malignant melanoma correlates with the depth of tumor invasion. Implications for tumor progression. Am. J. Pathol. 1994, 145, 97-104. [PubMed]

195. Polanska, U.M.; Orimo, A. Carcinoma-associated fibroblasts: Non-neoplastic tumour-promoting mesenchymal cells. J. Cell. Physiol. 2013, 228, 1651-1657. [CrossRef]

196. Wipff, P.J.; Rifkin, D.B.; Meister, J.J.; Hinz, B. Myofibroblast contraction activates latent TGF-beta1 from the extracellular matrix. J. Cell Biol. 2007, 179, 1311-1323. [CrossRef]

197. Pasco, S.; Brassart, B.; Ramont, L.; Maquart, F.X.; Monboisse, J.C. Control of melanoma cell invasion by type IV collagen. Cancer Detect. Prev. 2005, 29, 260-266. [CrossRef]

198. Najafi, M.; Farhood, B.; Mortezaee, K. Extracellular matrix (ECM) stiffness and degradation as cancer drivers. J. Cell. Biochem. 2019, 120, 2782-2790. [CrossRef]

199. Burchardt, E.R.; Hein, R.; Bosserhoff, A.K. Laminin, hyaluronan, tenascin-C and type VI collagen levels in sera from patients with malignant melanoma. Clin. Exp. Dermatol. 2003, 28, 515-520. [CrossRef]

200. Khan, H.Y.; Orimo, A. Transforming growth factor- $\beta$ : Guardian of catabolic metabolism in carcinoma-associated fibroblasts. Cell. Cycle 2012, 11, 4302-4303. [CrossRef]

201. Li, Z.; Zhang, J.; Zhou, J.; Lu, L.; Wang, H.; Zhang, G.; Wan, G.; Cai, S.; Du, J. Nodal facilitates differentiation of fibroblasts to cancer-associated fibroblasts that support tumor growth in melanoma and colorectal cancer. Cells 2019, 8, 538. [CrossRef] [PubMed] 
202. Topczewska, J.M.; Postovit, L.M.; Margaryan, N.V.; Sam, A.; Hess, A.R.; Wheaton, W.W.; Nickoloff, B.J.; Topczewski, J.; Hendrix, M.J. Embryonic and tumorigenic pathways converge via nodal signaling: Role in melanoma aggressiveness. Nat. Med. 2006, 12, 925-932. [CrossRef] [PubMed]

203. Kodet, O.; Dvořánková, B.; Bendlová, B.; Sýkorová, V.; Krajsová, I.; Štork, J.; Kučera, J.; Szabo, P.; Strnad, H.; Kolář, M.; et al. Microenvironment-driven resistance to B-raf inhibition in a melanoma patient is accompanied by broad changes of gene methylation and expression in distal fibroblasts. Int. J. Mol. Med. 2018, 41, 2687-2703. [CrossRef] [PubMed]

204. Pramong, N.; Gojaseni, P.; Suttipongkeat, S.; Kiattisunthorn, K.; Chittinandana, A. Diagnostic accuracy of fibroblast growth factor 23 for predicting acute kidney injury in patients with acute decompensated heart failure. Nephrology (Carlton) 2020, e13780. [CrossRef]

205. Carlino, M.S.; Long, G.V.; Kefford, R.F.; Rizos, H. Targeting oncogenic BRAF and aberrant MAPK activation in the treatment of cutaneous melanoma. Crit. Rev. Oncol. Hematol. 2015, 96, 385-398. [CrossRef]

206. Daniotti, M.; Oggionni, M.; Ranzani, T.; Vallacchi, V.; Campi, V.; Di Stasi, D.; Torre, G.D.; Perrone, F.; Luoni, C.; Suardi, S.; et al. BRAF alterations are associated with complex mutational profiles in malignant melanoma. Oncogene 2004, 23, 5968-5977. [CrossRef]

207. Uribe, P.; Wistuba, I.I.; González, S. BRAF mutation: A frequent event in benign, atypical, and malignant melanocytic lesions of the skin. Am. J. Dermatopathol. 2003, 25, 365-370. [CrossRef]

208. Vanni, I.; Tanda, E.T.; Spagnolo, F.; Andreotti, V.; Bruno, W.; Ghiorzo, P. The current state of molecular testing in the BRAF-mutated melanoma landscape. Front. Mol. Biosci. 2020, 7, 113. [CrossRef]

209. Halaban, R.; Krauthammer, M. RASopathy gene mutations in melanoma. J. Investig. Dermatol. 2016, 136, 1755-1759. [CrossRef]

210. Vanni, I.; Tanda, E.T.; Dalmasso, B.; Pastorino, L.; Andreotti, V.; Bruno, W.; Boutros, A.; Spagnolo, F.; Ghiorzo, P. Non-BRAF mutant melanoma: Molecular features and therapeutical implications. Front. Mol. Biosci. 2020, 7, 172. [CrossRef]

211. Platz, A.; Egyhazi, S.; Ringborg, U.; Hansson, J. Human cutaneous melanoma; A review of NRAS and BRAF mutation frequencies in relation to histogenetic subclass and body site. Mol. Oncol. 2008, 1, 395-405. [CrossRef] [PubMed]

212. Dantonio, P.M.; Klein, M.O.; Freire, M.R.V.B.; Araujo, C.N.; Chiacetti, A.C.; Correa, R.G. Exploring major signaling cascades in melanomagenesis: A rationale route for targetted skin cancer therapy. Biosci. Rep. 2018, 38. [CrossRef] [PubMed]

213. Dhomen, N.; Marais, R. New insight into BRAF mutations in cancer. Curr. Opin. Genet. Dev. 2007, 17, 31-39. [CrossRef] [PubMed]

214. Damsky, W.E.; Bosenberg, M. Melanocytic nevi and melanoma: Unraveling a complex relationship. Oncogene 2017, 36, 5771-5792. [CrossRef]

215. Kuwata, T.; Kitagawa, M.; Kasuga, T. Proliferative activity of primary cutaneous melanocytic tumours. Virchows Arch. A Pathol. Anat. Histopathol. 1993, 423, 359-364. [CrossRef]

216. Maldonado, J.L.; Timmerman, L.; Fridlyand, J.; Bastian, B.C. Mechanisms of cell-cycle arrest in spitz nevi with constitutive activation of the MAP-kinase pathway. Am. J. Pathol. 2004, 164, 1783-1787. [CrossRef]

217. Michaloglou, C.; Vredeveld, L.C.; Soengas, M.S.; Denoyelle, C.; Kuilman, T.; van der Horst, C.M.; Majoor, D.M.; Shay, J.W.; Mooi, W.J.; Peeper, D.S. BRAFE600-associated senescence-like cell cycle arrest of human naevi. Nature 2005, 436, 720-724. [CrossRef]

218. Gray-Schopfer, V.C.; Cheong, S.C.; Chong, H.; Chow, J.; Moss, T.; Abdel-Malek, Z.A.; Marais, R.; Wynford-Thomas, D.; Bennett, D.C. Cellular senescence in naevi and immortalisation in melanoma: A role for p16? Br. J. Cancer 2006, 95, 496-505. [CrossRef]

219. Dhomen, N.; Reis-Filho, J.S.; da Rocha Dias, S.; Hayward, R.; Savage, K.; Delmas, V.; Larue, L.; Pritchard, C.; Marais, R. Oncogenic BRAF induces melanocyte senescence and melanoma in mice. Cancer Cell 2009, 15, 294-303. [CrossRef]

220. Huang, J.M.; Chikeka, I.; Hornyak, T.J. Melanocytic nevi and the genetic and epigenetic control of oncogene-induced senescence. Dermatol. Clin. 2017, 35, 85-93. [CrossRef]

221. Uribe, P.; Andrade, L.; Gonzalez, S. Lack of association between BRAF mutation and MAPK ERK activation in melanocytic nevi. J. Investig. Dermatol. 2006, 126, 161-166. [CrossRef] [PubMed] 
222. Damsky, W.; Micevic, G.; Meeth, K.; Muthusamy, V.; Curley, D.P.; Santhanakrishnan, M.; Erdelyi, I.; Platt, J.T.; Huang, L.; Theodosakis, N.; et al. MTORC1 activation blocks BRAFV600E-induced growth arrest but is insufficient for melanoma formation. Cancer Cell 2015, 27, 41-56. [CrossRef] [PubMed]

223. Proietti, I.; Skroza, N.; Michelini, S.; Mambrin, A.; Balduzzi, V.; Bernardini, N.; Marchesiello, A.; Tolino, E.; Volpe, S.; Maddalena, P.; et al. BRAF Inhibitors: Molecular targeting and immunomodulatory actions. Cancers 2020, 12, 1823. [CrossRef] [PubMed]

224. Croce, L.; Coperchini, F.; Magri, F.; Chiovato, L.; Rotondi, M. The multifaceted anti-cancer effects of BRAF-inhibitors. Oncotarget 2019, 10, 6623-6640. [CrossRef] [PubMed]

225. Young, H.L.; Rowling, E.J.; Bugatti, M.; Giurisato, E.; Luheshi, N.; Arozarena, I.; Acosta, J.C.; Kamarashev, J.; Frederick, D.T.; Cooper, Z.A.; et al. An adaptive signaling network in melanoma inflammatory niches confers tolerance to MAPK signaling inhibition. J. Exp. Med. 2017, 214, 1691-1710. [CrossRef]

226. Diazzi, S.; Tartare-Deckert, S.; Deckert, M. Bad neighborhood: Fibrotic stroma as a new player in melanoma resistance to targeted therapies. Cancers 2020, 12, 1364. [CrossRef]

227. Atzori, M.G.; Ceci, C.; Ruffini, F.; Trapani, M.; Barbaccia, M.L.; Tentori, L.; D'Atri, S.; Lacal, P.M.; Graziani, G. Role of VEGFR-1 in melanoma acquired resistance to the BRAF inhibitor vemurafenib. J. Cell. Mol. Med. 2020, 24, 465-475. [CrossRef]

228. Khalili, J.S.; Liu, S.; Rodríguez-Cruz, T.G.; Whittington, M.; Wardell, S.; Liu, C.; Zhang, M.; Cooper, Z.A.; Frederick, D.T.; Li, Y.; et al. Oncogenic BRAF(V600E) promotes stromal cell-mediated immunosuppression via induction of interleukin-1 in melanoma. Clin. Cancer Res. 2012, 18, 5329-5340. [CrossRef]

229. Fedorenko, I.V.; Wargo, J.A.; Flaherty, K.T.; Messina, J.L.; Smalley, K.S.M. BRAF inhibition generates a host-tumor niche that mediates therapeutic escape. J. Investig. Dermatol. 2015, 135, 3115-3124. [CrossRef]

230. Hirata, E.; Girotti, M.R.; Viros, A.; Hooper, S.; Spencer-Dene, B.; Matsuda, M.; Larkin, J.; Marais, R.; Sahai, E. Intravital imaging reveals how BRAF inhibition generates drug-tolerant microenvironments with high

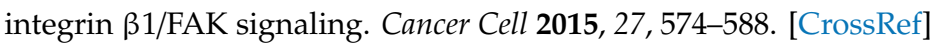

Publisher's Note: MDPI stays neutral with regard to jurisdictional claims in published maps and institutional affiliations.

(C) 2020 by the authors. Licensee MDPI, Basel, Switzerland. This article is an open access article distributed under the terms and conditions of the Creative Commons Attribution (CC BY) license (http://creativecommons.org/licenses/by/4.0/). 